\title{
Nutrient uplift in a cyclonic eddy increases diversity, primary productivity and iron demand of microbial communities relative to a western boundary current
}

Martina A Doblin, Katherina Petrou, Sutinee Sinutok, Justin R Seymour, Lauren F Messer, Mark V Brown, Louiza Norman, Jason D Everett, Allison S McInnes, Peter J Ralph, Peter A Thompson, Christel S Hassler

The intensification of western boundary currents in the global ocean will potentially influence meso-scale eddy generation, and redistribute microbes and their associated ecological and biogeochemical functions. To understand eddy-induced changes in microbial community composition as well as how they control growth, we targeted the East Australian Current (EAC) region to sample microbes in a cyclonic (cold-core) eddy (CCE) and the adjacent EAC. Phototrophic and diazotrophic microbes were more diverse (2 to 10 times greater Shannon index) in the CCE relative to the EAC, and the cell size distribution in the CCE was dominated (67\%) by larger micro-plankton ( $\geq 20 \mu \mathrm{m}$ ), as opposed to picoand nano-sized cells in the EAC. Nutrient addition experiments determined that nitrogen was the principal nutrient limiting growth in the EAC, while iron was a secondary limiting nutrient in the CCE. Among the diazotrophic community, heterotrophic NifH gene sequences dominated in the EAC and were attributable to members of the gamma-, beta-, and delta-proteobacteria, while the CCE contained both phototrophic and heterotrophic diazotrophs, including Trichodesmium, UCYN-A and gamma-proteobacteria. Daily sampling of incubation bottles following nutrient amendment captured a cascade of effects at the cellular, population and community level, indicating taxon-specific differences in the speed of response of microbes to nutrient supply. Nitrogen addition to the CCE community increased picoeukaryote chlorophyll a quotas within $24 \mathrm{~h}$, suggesting that nutrient uplift by eddies causes a 'greening' effect as well as an increase in phytoplankton biomass. After three days in both the EAC and CCE, diatoms increased in abundance with macronutrient $(\mathrm{N}, \mathrm{P}, \mathrm{Si})$ and iron amendment, whereas haptophytes and phototrophic dinoflagellates declined. Our results indicate that cyclonic eddies increase delivery of nitrogen to the upper ocean to potentially mitigate the negative consequences of increased stratification due to ocean warming, but also increase the biological demand for iron that is necessary to sustain the growth of large-celled phototrophs and potentially support the diversity of diazotrophs over longer time-scales. 
1 Nutrient uplift in a cyclonic eddy increases diversity, primary productivity and iron demand of microbial communities relative to a western boundary current

3

4 M.A. Doblin 1 , K. Petrou ${ }^{2}$, S. Sinutok ${ }^{1,3}$, J. Seymour ${ }^{1}$, L.F. Messer ${ }^{1}$, M.V. Brown ${ }^{4}$, L. Norman ${ }^{1,5}$, $5 \quad$ J.D. Everett ${ }^{6}$, A. McInnes ${ }^{1}$, P. J. Ralph ${ }^{1}$, P.A. Thompson ${ }^{7}$, C. Hassler ${ }^{8}$

6 1. Plant Functional Biology and Climate Change Cluster, University of Technology Sydney,

7 Ultimo, NSW, Australia

8 2. School of Life Sciences, University of Technology Sydney, Ultimo, NSW, Australia

9 3. Faculty of Environmental Management, Prince of Songkla University, Kho Hong, Songkhla 10 90112, Thailand

11 4. School of Biotechnology and Biomolecular Sciences, University of New South Wales, 12 Randwick, NSW, Australia

13 5. Department of Plant Sciences, University of Cambridge, Cambridge, United Kingdom

6. School of Biological, Earth and Environmental Sciences, University of New South Wales,

7. Oceans and Atmosphere Flagship, Commonwealth Scientific Industrial Research Organisation, , Hobart, Australia.

8. Institute F.-A. Forel, Earth and Environmental Sciences, University of Geneva, Geneva, Switzerland

Corresponding author:

Martina Doblin

Plant Functional Biology and Climate Change Cluster, University of Technology Sydney, Thomas Street, Ultimo, NSW, 2007, Australia

Martina.Doblin@uts.edu.au 
28 Abstract

29 The intensification of western boundary currents in the global ocean will potentially influence

30 meso-scale eddy generation, and redistribute microbes and their associated ecological and

31 biogeochemical functions. To understand eddy-induced changes in microbial community

32 composition as well as how they control growth, we targeted the East Australian Current (EAC)

33 region to sample microbes in a cyclonic (cold-core) eddy (CCE) and the adjacent EAC.

34 Phototrophic and diazotrophic microbes were more diverse (2 to 10 times greater Shannon

35 index) in the CCE relative to the EAC, and the cell size distribution in the CCE was dominated

$36(67 \%)$ by larger micro-plankton $(\geq 20 \mu \mathrm{m})$, as opposed to pico- and nano-sized cells in the EAC.

37 Nutrient addition experiments determined that nitrogen was the principal nutrient limiting

38 growth in the EAC, while iron was a secondary limiting nutrient in the CCE. Among the

39 diazotrophic community, heterotrophic NifH gene sequences dominated in the EAC and were

40 attributable to members of the gamma-, beta-, and delta-proteobacteria, while the CCE contained

41 both phototrophic and heterotrophic diazotrophs, including Trichodesmium, UCYN-A and

42 gamma-proteobacteria. Daily sampling of incubation bottles following nutrient amendment

43 captured a cascade of effects at the cellular, population and community level, indicating taxon-

44 specific differences in the speed of response of microbes to nutrient supply. Nitrogen addition to

45 the CCE community increased picoeukaryote chlorophyll $a$ quotas within $24 \mathrm{~h}$, suggesting that

46 nutrient uplift by eddies causes a 'greening' effect as well as an increase in phytoplankton

47 biomass. After three days in both the EAC and CCE, diatoms increased in abundance with

48 macronutrient $(\mathrm{N}, \mathrm{P}, \mathrm{Si})$ and iron amendment, whereas haptophytes and phototrophic

49 dinoflagellates declined. Our results indicate that cyclonic eddies increase delivery of nitrogen to

50 the upper ocean to potentially mitigate the negative consequences of increased stratification due

51 to ocean warming, but also increase the biological demand for iron that is necessary to sustain 
52 the growth of large-celled phototrophs and potentially support the diversity of diazotrophs over

53 longer time-scales.

54

55

56

57 


\section{Introduction}

60 There are two broad nutrient limitation regimes for phytoplankton growth in the contemporary

61 ocean, whereby iron (Fe) limitation occurs across $\sim 30 \%$ of the ocean's surface area where high

62 macronutrient concentrations occur (high latitudes, upwelling and some coastal areas), and

63 nitrogen $(\mathrm{N})$ limitation occurs across most of the oligotrophic low-latitude systems (Moore et al.

64 2013). Different phytoplankton groups can have specific nutrient requirements, such as Fe for

65 diazotrophs (Kustka et al 2003) and silicon (Si) for diatoms (Brzezinski \& Nelson 1989), which

66 may lead to secondary or interactive effects on Fe or $\mathrm{N}$ limitation. Co-limitation may also arise

67 when there is physical mixing between water masses with different nutrient stoichiometry, or

68 over seasonal cycles when physical nutrient inputs and biological cycling alters nutrient

69 bioavailability (Deutsch \& Weber 2012).

70 Global Climate Model (GCM) projections indicate warming and increased stratification of the

71 upper ocean over the coming decades, limiting the upwards delivery of nitrogen (e.g., "new” N)

72 into the euphotic zone, and potentially leading to increased reliance on a smaller pool of

73 regenerated forms or $\mathrm{N}$ fixation to support primary production (Behrenfeld 2011). However,

74 these models typically do not consider the influence of smaller scale oceanographic features such

75 as meso-scale eddies, which could act as a compensatory mechanism and enrich the upper ocean

76 with new nutrients delivered from deeper ocean waters, potentially mitigating the negative

77 consequences of climate change (Matear et al. 2013).

78 While eddies are universal features of the global ocean (Chelton, Schlax \& Samelson 2011), they

79 differ in their mode of formation, direction of rotation, size, longevity, and processes driving nutrient dynamics (e.g. interaction between wind and surface currents, horizontal entrainment; 
81 Gaube et al. 2014), and can thus have different biological effects (Bibby et al. 2008). Eddies

82 formed in coastal regions, for example, can entrain enriched continental shelf water (Waite et al.

83 2007), and consequently have higher positive chlorophyll-a anomalies than their oceanic

84 counterparts (Everett et al. 2012). The ratio of upwelled nutrients (e.g., Si:N) delivered into the

85 euphotic zone is also important in determining the structure of microbial communities sustained

86 by eddies and influences their biogeochemical function (Bibby \& Moore 2011). Therefore, the

87 role eddies play in regulating internal nutrient inputs from the deep ocean is likely to be

88 regionally dependent.

89 Much of what is known about eddies and their impact on the base of the foodweb is derived from

90 satellite ocean colour observations which provide limited information with respect to microbial

91 species composition and biogeochemical activity, and have a restricted view of the upper ocean

92 (McGillicuddy 2016). In situ observations and manipulative experiments are therefore critical to

93 develop a full understanding of the role of meso-scale eddies in upper-ocean ecosystem

94 dynamics and biogeochemical cycling.

95 Australia has one of the longest north-south coastlines in the world, and the oceanography along

96 its east coast is extremely dynamic. It is strongly influenced by the flow of the Eastern Australian

97 Current (EAC), one of five western boundary currents (WBCs) in the global ocean. Southward of

$98 \sim 32{ }^{\circ} \mathrm{S} 153{ }^{\circ} \mathrm{E}$, where two thirds of the EAC deviates eastward towards New Zealand to form the

99 Tasman Front, the remaining EAC flow meanders, breaking down into a complex series of meso-

100 scale eddies (Ridgway \& Godfrey, 1997). The number and frequency of these eddies is higher

101 than in the broader Tasman Sea, and their biological properties differentiate more strongly from

102 background ocean waters than their oceanic counterparts (Everett et al. 2014). A critical research

103 question is whether the observed intensification of the EAC (Wu et al., 2012) will result in more 
104 eddies, a change in the nature of these eddies, and how they will impact on primary producers

105 and higher trophic levels.

106 Given that offshore phytoplankton communities in the Tasman Sea are generally N limited

107 (Hassler et al. 2011; Ellwood et al. 2013), and that cyclonic cold-core eddies displace isopycnal

108 surfaces (seawater of similar density) upwards and can upwell nutrients into the euphotic zone

109 (McGillicuddy et al., 1998), EAC-induced eddies could increase the supply of nitrogen into

110 surface waters from below the thermocline and potentially alter controls on phytoplankton

111 growth. However, another source of $\mathrm{N}$ into surface waters is from $\mathrm{N}_{2}$ fixing microbes. At least

112 four different groups of diazotrophs have been identified from Australian waters: the

113 filamentous, photosynthetic cyanobacterium Trichodesmium, the unicellular phycoerythrin-

114 containing cyanobacterium Crocosphaera watsonii (group B), the photoheterotrophic symbiont

115 UCYN-A (associated with specific prymnesiophyte hosts; Hagino et al. 2013), and heterotrophic

116 proteobacteria (Moisander et al. 2010; Seymour et al. 2012; Messer et al. 2015). The regional

117 distribution of diazotrophs in the western South Pacific suggests there is a sufficient supply of Fe

118 to satisfy the requirements of the nitrogenase enzyme (Kustka et al 2003), but little is known

119 about how eddies may change the delivery of Fe or $\mathrm{N}$ from depth in this region, and hence alter

120 the dynamics of diazotrophs relative to other microbial groups.

121 This study targeted the western Tasman Sea, which is dominated by the East Australian Current

122 (EAC) and its associated eddy field. We examined the composition and diversity of the microbial

123 community in a cyclonic cold core eddy (CCE) and in the EAC, and examined their responses to

124 separate additions of nitrate $(\mathrm{N})$, nitrate with iron $(\mathrm{NFe})$, silicic acid $(\mathrm{Si})$ as well as a mix of

125 nutrients containing $\mathrm{N}, \mathrm{Fe}, \mathrm{Si}$ and phosphate $(\mathrm{P})$. We focused on communities from the

126 subsurface chlorophyll-a maximum to simulate the impact of moderate nutrient uplift into the 
127 euphotic zone (i.e., upwelling that does not reach the surface), and advance knowledge about

128 responses of microbial communities that are difficult to detect using satellites.

\section{Materials and Methods}

131

132

Study site and water collection. The experiments were conducted on the $R V$ Southern Surveyor during austral spring in 2010 (15 - 31 October) between 29 and $36^{\circ} \mathrm{S}$, and 150 and $155^{\circ} \mathrm{E}$ (Fig. 1A). Sampling sites were chosen with the assistance of daily Moderate Resolution Imaging Spectroradiometer (MODIS) and Advanced Very High Resolution Radiometer (AVHRR) satellite imagery and targeted the EAC and a meso-scale cyclonic (cold core) eddy (CCE; Fig. 1B). To examine the oceanographic context of the sampling period, MODIS Level 3 sea-surface temperature was obtained from the Integrated Marine Observing System (IMOS) Data Portal (http://imos.aodn.org.au/imos/) at $1 \mathrm{~km}$ resolution. Satellite altimeter data were obtained from NASA/CNES (Jason-1 and 2) and ESA (ENVISAGE) via the IMOS portal.

At each site, the physico-chemical properties of the water column $(0-200 \mathrm{~m})$ were measured with the aid of a Conductivity-Temperature-Depth (CTD; Seabird SBE911-plus) equipped with a fluorometer (AquaTracker Mk3, Chelsea, UK), transmissometer (Wetlabs C-Star (25cm optical path)), dissolved oxygen (Seabird SBE43) and Photosynthetically Active Radiation (PAR; Biospherical Instruments QCP-2300 Log Quantum Cosine Irradiance Sensor) sensor.

Seawater used to assess microbial composition and diversity, as well as for nutrient amendment experiments was collected from the depth of the chlorophyll $a(\mathrm{Chl}-\mathrm{a})$ fluorescence maximum (as determined by the down-cast fluorescence profile) using $10 \mathrm{~L}$ Niskin bottles $(80 \mathrm{~m}$ in the $\mathrm{EAC}$, and $41 \mathrm{~m}$ in the $\mathrm{CCE}$ ). A trace metal clean rosette was not available for this voyage, so the 
150 following precautions were taken to minimise trace metal contamination. Water was sampled

151 from Niskin bottles through acid washed silicon tubing with plastic bags covering the tubing and

152 bottle neck, and polyethelene gloves were worn during water sampling and manipulation.

153 Seawater was filtered through acid-soaked 200-210 $\mu \mathrm{m}$ mesh to remove mesozooplankton

154 grazers and collected in $20 \mathrm{~L}$ acid washed (1 N HCl, rinsed 7-times with MilliQ water) LDPE or

155 PC carboys. Carboys were stored in double-plastic bags and kept in plastic boxes to avoid 156 contact with the ship. All subsequent sampling took place in a custom-made, metal free laminar

157 flow cabinet, dedicated for trace metal clean work using standard clean room procedures.

158 Experimental setup. Water was homogenised, sampled for dissolved nutrients, flow cytometry, 159 phytoplankton pigments, nucleic acid collection and photo-physiological measurements, with the 160 remainder transferred into pre-treated acid washed (1 $\mathrm{N} \mathrm{HCl}$, rinsed 7-times with MilliQ water) 4 161 L polycarbonate bottles (Nalgene) under laminar flow conditions. Bottles were randomly 162 allocated to five nutrient addition treatments in triplicate: an unamended control, $+\mathrm{NO}_{3}(10 \mu \mathrm{M}$ 163 nitrate final concentration), $+\mathrm{NO}_{3}+\mathrm{FeCl}_{3}(10 \mu \mathrm{M}$ and $1 \mathrm{nM}$ final concentration (ICP-MS $1 \mathrm{~g} / \mathrm{L}$ 164 standard, Fluka), respectively), $+\mathrm{Si}(\mathrm{OH})_{4} \quad(10 \mu \mathrm{M}$ final concentration), nutrient mix $165\left(+\mathrm{NO}_{3}+\mathrm{Si}+\mathrm{PO}_{4}+\mathrm{Fe} ; 10 \mathrm{~N}: 10 \mathrm{Si}: 0.625 \mathrm{P} \mu \mathrm{M}\right.$ in Redfield proportions and $1 \mathrm{nM} \mathrm{Fe}$ respectively $)$. 166 After the addition of nutrients, bottles were capped, gently inverted and lids sealed with parafilm, 167 before being placed into an on-deck, flow-through incubator, exposed to $25 \%$ surface irradiance 168 and in situ temperature conditions.Surface seawater supplying the deck board incubators was $16921.94 \pm 0.47$ during the EAC incubation and $21.57 \pm 0.27$ during the CCE incubations. This 170 closely matches the in situ temperature for both EAC $(80 \mathrm{~m})$ and CCE $(41 \mathrm{~m})$ communities at the 171 time of sampling (Table 1). 
172 For the EAC experiment, control bottles were sampled daily for maximum quantum yield of

173 photosystem II $\left(\mathrm{F}_{\mathrm{V}} / \mathrm{F}_{\mathrm{M}}\right)$ before being enriched with their respective nutrient or nutrient mix

174 treatment, then re-sealed and returned to the on-deck incubator. The same sampling protocol was

175 used in the CCE; however, no additional nutrient additions were made after the initial

176 amendment to avoid accumulation of excess nutrients. To limit nutrient or microbiological cross-

177 contamination, the same bottles were re-used for identical experimental (nutrient) treatments

178 across the EAC and CCE experiments. Macronutrient analyses were carried out on board by

179 CSIRO Marine and Atmospheric Research (CMAR) according to Cowley et al. (1999). Nutrient

180 measurements had a standard error $<0.7 \%$ and a detection limit of $0.035 \mu \mathrm{M}$ for $\mathrm{NO}_{\mathrm{x}}, 0.012 \mu \mathrm{M}$

181 for $\mathrm{Si}$ and $0.009 \mu \mathrm{M}$ for $\mathrm{PO}_{4}$.

182 After 3 days (72 - 78 h) of incubation, nutrient experiments were terminated. Microbial 183 responses to nutrient additions were quantified by measuring pigments (Chl-a and other 184 accessory pigments), abundance of pico- and nano-phytoplankton and heterotrophic bacteria via 185 flow cytometry, and DNA sequencing for characterising prokaryote and diazotroph community 186 diversity and composition (16S ribosomal RNA, nitrogenase NifH subunit targeted, 187 respectively).

Pigment Analysis. Seawater (minimum volume 2.2 L) was filtered under low vacuum (e.g. $\leq$ $100 \mathrm{~mm} \mathrm{Hg})$ onto $25 \mathrm{~mm} \mathrm{GF/F}$ filters in low light $\left(<10 \mu \mathrm{mol}\right.$ photons $\left.\mathrm{m}^{-2} \mathrm{~s}^{-1}\right)$. Filters were folded in half, blotted dry on absorbent paper, placed into screw-capped cryovials and stored in liquid nitrogen until pigment analysis. In the laboratory, pigments were extracted and analysed

192 using High Performance Liquid Chromatography (HPLC) as described in Hassler et al. (2011).

193 Biomarker pigments were used to infer the distribution of dominant phototrophs. Each biomarker 194 pigment was normalised against chlorophyll-a (the universal pigment in all phytoplankton) to 
195 account for spatial variation in the total phytoplankton biomass. Briefly, biomarkers represent the

196 following phytoplankton groups: Zeaxanthin (Zea) = cyanobacteria; 19'Hexanoyloxyfucoxanthin

$197(19-$ Hex $)=$ haptophytes; Chlorophyll b $(\mathrm{Chl}-\mathrm{b})$ and lutein $=$ Chlorophytes; Alloxanthin $($ Allo $)=$ 198 cryptophytes, 19'Butanoloxylfucoxanthin $(19-B u t)=$ pelagophytes; Prasinoxanthin $($ Prasino $)=$ 199 prasinophytes; Peridinin $($ Per $)=$ autotrophic dinoflagellates; and Fucoxanthin $($ Fuco $)=$ diatoms, 200 prymnesiophytes, chrysophytes, pelagophytes and raphidophytes. The photosynthetic (PSC) and 201 photoprotective (PPC) carotenoid pigment contributions were calculated as in Barlow et al. 202 (2007), and the approach of Uitz et al. (2008) was used to assess the taxonomic composition of 203 the phytoplankton community and characterise its size structure. While this method may be 204 subject to error because pigments are shared between different phytoplankton groups, and some 205 groups are spread across different sizes, we apply it in this study to examine relative (not 206 absolute) differences in size structure between water masses and nutrient treatments.

207 Flow Cytometry. Samples for enumeration of pico- and nano-phytoplankton were fixed with 208 glutaraldehyde ( $1 \% \mathrm{v} / \mathrm{v}$ final concentration), snap frozen in liquid nitrogen and stored at $-80^{\circ} \mathrm{C}$. 209 Populations of Prochlorococcus, Synechococcus and picoeukaryotes were discriminated using 210 side scatter (SSC) and red and orange fluorescence (Marie et al. 1997) using a flow cytometer 211 (LSR II, BD Biosciences). Pigment content per cell was normalised to the fluorescence of 212 standard yellow-green beads (1 $\mathrm{m}$ FluoSpheres ${ }^{\circledR}$, Life Technologies) that were added to each 213 sample immediately before analysis. Samples for bacterial analysis were stained with SYBR 214 Green I nucleic acid stain (1:10000 final dilution; Molecular Probes) (Marie et al. 1997) and high 215 and low nucleic acid content populations were discriminated according to green fluorescence and 216 side scatter properties (Gasol \& Del Giorgio 2000; Seymour, Seuront \& Mitchell 2007). Data 217 was analysed using Cell-Quest Pro (BD Biosciences). 
218 DNA extraction and sequence analysis of prokaroyote and diazotrophic communities.

219 Water samples (2 L) for DNA analyses were filtered onto $0.2 \mu \mathrm{m}$ polycarbonate membrane

220 filters (Millipore), snap frozen in liquid nitrogen and stored at $-80{ }^{\circ} \mathrm{C}$ prior to analysis. Genomic

221 DNA was subsequently extracted using the Power Water DNA extraction kit (MoBio

222 Laboratories, Inc) following the manufacturer's protocols and DNA concentration was quantified

223 using a Qubit® 2.0 fluorometer (Invitrogen). To determine bacterial community composition, the

224 V1-V3 region of the 16S rRNA gene was amplified using the primer sets in Table S1, and

225 sequenced by 454 pyrosequencing (Roche, FLX Titanium; Molecular Research LP) following

226 previously published protocols (Acosta-Martínez et al. 2008; Dowd et al. 2008). 16S rRNA gene

227 sequences were analysed and processed using the Quantitative Insights into Microbial Ecology

228 software (QIIME; Caporaso et al. 2010). Briefly, samples were quality filtered, de-multiplexed

229 and clustered based on $97 \%$ sequence identity using UCLUST (Edgar 2010). Taxonomy was

230 assigned according to the latest version of the SILVA database (111; Quast et al. 2013) and

231 samples were rarefied to the lowest number of sequences to ensure even sampling effort across

232 samples $(14,621$ sequences per sample).

233 For $\mathrm{N}_{2}$-fixing bacteria, the gene encoding a subunit of the enzyme nitrogenase (NifH, Zehr,

234 Mellon \& Hiorns 1997; Zehr et al. 2003) was amplified and sequenced from genomic DNA

235 using previously published methods (Zehr \& McReynolds 1989; Zehr \& Turner 2001). A nested

236 PCR protocol was used to amplify an approximately $359 \mathrm{bp}$ region of the NifH gene using two

237 sets of degenerate primers listed in Table S1. PCR products were purified using the Ultra Clean

238 PCR Clean-up Kit (MoBio Laboratories, Inc) following the manufacturer's instructions. The

239 nifH amplicons were sequenced by 454 pyrosequencing (Roche, FLX Titanium; Molecular

240 Research LP) after an additional 10-cycles PCR with custom barcoded NifH1 and NifH2 primers 
241 under the same reaction conditions (Dowd et al. 2008; Farnelid et al. 2011, 2013). Raw

242 sequences were quality filtered, and de-multiplexed in QIIME (Caporaso et al. 2010). Sequences

243 were clustered at $95 \%$ sequence identity using UCLUST, whereby $n N i f H$ sequences within 5\%

244 identity of a centroid read were assigned as operational taxonomic units (OTUs) (Edgar 2010),

245 then rarefied to 1,050 sequences per sample to ensure even sampling effort, resulting in $989 \mathrm{NifH}$

246 OTUs. Since many of these NifH OTUs were singletons, only OTUs with $\geq 100$ sequences

247 assigned to them were analysed further (representing $85 \%$ of total $\mathrm{NifH}$ sequences), resulting in

24816 OTUs. Putative taxonomy was assigned using BLASTn (Altschul et al. 1990) against the

249 NCBI Nucleotide collection database, and translated NifH sequences were compared to the

250 Ribosomal Database Project's NifH protein database using FrameBot (Wang et al. 2013; Fish et

251 al. 2013).

252 Photophysiological measurements. Photosynthetic efficiency of microbial phototrophs was

253 measured using a Pulse Amplitude Modulated (PAM) fluorometer (Water-PAM; Walz GmbH,

254 Effeltrich, Germany). A $3 \mathrm{ml}$ aliquot of water was transferred to a quartz cuvette and after a 10

255 min dark-adaptation period, minimum fluorescence $\left(\mathrm{F}_{\mathrm{O}}\right)$ was recorded. Upon application of a

256 saturating pulse of light (pulse duration $=0.8 \mathrm{~s}$; pulse intensity $>3000 \mu \mathrm{mol}$ photons $\mathrm{m}^{-2} \mathrm{~s}^{-1}$ )

257 maximum fluorescence $\left(\mathrm{F}_{\mathrm{M}}\right)$ was determined. From these two parameters, $\mathrm{F}_{\mathrm{V}} / \mathrm{F}_{\mathrm{M}}$ was calculated

258 according to the equation $\left(\mathrm{F}_{\mathrm{M}}-\mathrm{F}_{\mathrm{O}}\right) / \mathrm{F}_{\mathrm{M}}($ Schreiber 2004).

259 Phytoplankton primary production measurements. Phytoplankton primary production was

260 estimated at the end of the 3-day experiments using small volume ${ }^{14} \mathrm{C}$ incubations as described in

261 Doblin et al. (2011). Carbon uptake rates were normalised to in situ chlorophyll $a$ concentrations.

262 Carbon fixation-irradiance relationships were then plotted and the equation of Platt, Gallegos \&

263 Harrison(1980) used to fit curves to data using least squares non-linear regression. 
264 Photosynthetic parameters included light-saturated photosynthetic rate $\left[\mathrm{P}_{\max }, \mathrm{mg} \mathrm{C}(\mathrm{mg} \mathrm{Chl}-\mathrm{a})^{-1}\right.$

$265 \mathrm{~h}^{-1}$, initial slope of the light-limited section of the carbon fixation-irradiance curve $[\alpha, \mathrm{mg} \mathrm{C}(\mathrm{mg}$

$\left.266 \mathrm{Chl}-\mathrm{a})^{-1} \mathrm{~h}^{-1}\left(\mu \mathrm{mol} \text { photons } \mathrm{m}^{-2} \mathrm{~s}^{-1}\right)^{-1}\right]$, and light intensity at which carbon-uptake became maximal

267 (calculated as $\mathrm{P}_{\max } / \alpha=\mathrm{E}_{\mathrm{k}}, \mu \mathrm{mol}$ photons $\mathrm{m}^{-2} \mathrm{~s}^{-1}$ ).

268 Statistical analysis. Differences in microbial composition and diversity between the initial EAC 269 and CCE communities, and between nutrient treatments within each water mass were assessed 270 using analysis of variance (ANOVA; $\alpha=0.05$ ). Data were analysed comparing responses at the 271 end of incubation, $\mathrm{t}_{72}(72-78 \mathrm{~h})$, across treatments, as well as comparing the differences over 272 time from the initial water $\left(t_{0}\right)$ to $t_{72}$. Multiple comparison adjustment of the $p$-value was made 273 using a Tukey's HSD test. To ensure that the assumption of equal variances for all parametric 274 tests was satisfied, a Levene's test for homogeneity of variance was applied to all data a priori 275 and when necessary, data was transformed. All analyses were performed using SPSS statistical 276 software (version 22, IBM, New York USA).

277 To examine overall changes in microbial assemblages due to nutrient amendment, composition 278 data (i.e. for phototrophs, diagnostic pigments standardised to total Chl-a, flow cytometric 279 counts; for heterotrophs and diazotrophs, rarefied 16S and NifH sequence data, respectively) were square root transformed and a resemblance matrix was generated using Bray-Curtis similarity in the PRIMER software package (Clarke \& Warwick 2001). Analysis of similarities (ANOSIM) was used to test the hypothesis that different nutrient amendments would influence microbial composition (Clarke 1993). The contribution of phytoplankton groups to the observed significant differences in community assemblage, as a function of treatment, were determined using Similarity Percentage Analysis (SIMPER; Clarke 1993). 


\section{Results}

288 Oceanographic setting. During the voyage, the EAC was flowing southward along the continental shelf edge (Fig. 1B) with a core surface temperature of $23-24{ }^{\circ} \mathrm{C}$. The EAC surface

290 velocity was $1.2 \mathrm{~m} \mathrm{~s}^{-1}$ estimated from altimetry (Fig. 1B, arrows) with the current separating 291 from the coast at $\sim 30{ }^{\circ} \mathrm{S}$, forming the Tasman Front. The EAC station (Fig. 1B) had a 292 temperature range of 21.4 to $22.5^{\circ} \mathrm{C}$ and a salinity of 35.45 to 35.52 in the upper $200 \mathrm{~m}$ of the 293 water-column. The cyclonic eddy, south of the EAC station, was sampled on $25^{\text {th }}$ October 2015 294 when it centred at $32{ }^{\circ} \mathrm{S}$ adjacent to the continental shelf. The CCE had a temperature range of 14.3 to $21.8{ }^{\circ} \mathrm{C}$ and a salinity of 35.26 to 35.54 in the upper $200 \mathrm{~m}$ of the water-column.

Dissolved macronutrient stocks indicated the potential for widespread $\mathrm{N}$ limitation in the EAC and adjacent shelf and Tasman Sea (offshore) waters (Fig. 2A), with nitrate deficit $\left(\mathrm{N}^{*}=\left[\mathrm{NO}_{3}{ }^{-}\right]\right.$ $-16\left[\mathrm{PO}_{4}{ }^{3-}\right]$ ) occurring to at least $200 \mathrm{~m}$ (overall mean for all depths $\pm \mathrm{SD}=-1.9 \pm 0.53 \mu \mathrm{M}$; Fig. and CCE (41 m), ranging between 0.1 and $0.3 \mu \mathrm{M}$ (Fig. 3), with dissolved phosphate being $\sim 0.1$ $\mu \mathrm{M}$ in both water masses (Table 1).

302

Microbial community composition and diversity in different water masses. Initial Chl-a concentrations were relatively low $\left(0.106\right.$ and $\left.0.336 \mu \mathrm{g} \mathrm{L}^{-1}\right)$, but distinct ( $\mathrm{p}$-value $\left.<0.05\right)$, in the EAC and CCE, respectively (Table 1; t0 Fig. 4A and B). The most abundant phototroph in the EAC was the cyanobacterium Prochlorococcus, whereas in the CCE it was Synechocccus (Fig. S1). A significant proportion of larger phototrophs in the EAC contained 19'hexanoyloxyfucoxanthin (Hex-Fuco; t0 Fig 4E), exclusively found in haptophytes, including the coccolithophores (Liu et al. 2009). However, in the CCE, fucoxanthin (found in Phaeophyta and most other heterokonts), was the dominant accessory pigment, largely indicative of diatoms (t0 
310 Fig. 4D). Pigment ratios suggested the size structure of the EAC phototrophic community was

311 dominated by pico- and nano-plankton $(<2 \mu \mathrm{m})$ and in the CCE by microplankton $(\geq 20 \mu \mathrm{m} ;$ t0

312 Fig. 5A and B, respectively). Pigment richness was 30\% higher in the CCE than in the EAC, and

313 phototrophic alpha-diversity was $\sim 40 \%$ higher (Shannon's index calculated using HPLC pigment

314 data $=1.02 \pm 0.05$ compared to $0.64 \pm 0.02$ in the EAC; average \pm SD here and throughout).

315 With respect to the heterotrophs, the total abundance of bacteria was similar in both water

316 masses $\left(\sim 8.5 \times 10^{5}\right.$ cells $\mathrm{ml}^{-1}$; t0 Fig. 5I and $\left.\mathrm{J}\right)$ but there was a greater proportion of high DNA

317 bacteria in the CCE (47 \pm 4 vs $39 \pm 2 \%$ in the EAC). The greatest proportion of bacterial $16 \mathrm{~S}$

318 rRNA sequences in both water masses belonged to the alpha-proteobacteria (SAR11 and

319 SAR116 clade), Rhodobacteriaceae, as well as Synechococcus and Prochlorococcus (Fig. 6) but

320 there was no difference in bacterial alpha-diversity between water masses (Shannon's index in

$321 \mathrm{EAC}=3.20 \pm 0.13$ compared to $3.10 \pm 0.19$ in the CCE). Heterotrophic NifH gene sequences

322 were detected in the EAC and were primarily attributable to members of the gamma-, beta-, and

323 delta-proteobacteria. Initial CCE samples were not available (cryovials broken in storage);

324 however control CCE treatments contained phototrophic and heterotrophic diazotrophs,

325 including Trichodesmium, UCYN-A and gamma-proteobacterial NifH sequences.

326 Nutrient-induced shifts in the phototrophic community. After 3 days, there was a large

327 positive effect of $\mathrm{NFe}$ and the nutrient $\mathrm{Mix}(\mathrm{N}, \mathrm{P}, \mathrm{Si}, \mathrm{Fe})$ on the total $\mathrm{Chl}-\mathrm{a}$ concentration in the

328 EAC community (Fig. 4A), which occurred alongside an increase in fucoxanthin relative to Chl a

329 in the NFe and Mix treatments ( $p$-value $\leq 0.026$; Fig. 4C), suggesting a greater relative

330 abundance of diatoms (Table 2). The relative abundance of haptophytes (as indicated by pigment

331 Hex-Fuco) showed a declining trend across all treatments, but by the end of the experiment

332 haptophytes were least abundant in the NFe treatment ( $p$-value $\leq 0.031$; Fig. 4E). 
333 Prochlorococcus (as determined by flow cytometric counts) decreased in all treatments including

334 the controls (Fig. 5G), but Synechococcus abundance declined only in the Mix treatment (Fig.

335 5E). Collectively, there was a decrease in picoeukaryote abundance in all but the NFe EAC

336 bottles by day 3 (p-value $<0.05$; Table 2 ), with the phototrophic community overall showing a

337 significant cell size increase into the micro size class (nominally $\geq 20 \mu \mathrm{m}$ ) with $\mathrm{N}$ amendment

338 (p-value $<0.05$; Fig. 5A), as estimated through pigment ratios (Uitz et al. 2008). Taken as a

339 whole, the largest shift in phototrophic community composition and structure was in the mix

340 treatment relative to all other treatments (SIMPER, $>75 \%$ dissimilarity), which was attributed

341 mainly to the decrease in picoeukaryotes. Importantly, the EAC community was more similar to

342 the $\mathrm{t}_{0}$ CCE community after nutrient amendment, particularly with NFe addition (Global $\mathrm{R}=$

3430.48, p-value $<0.05$; Fig 7C).

344 In contrast, within the CCE, addition of $\mathrm{N}, \mathrm{NFe}$ and Mix caused a significant increase in Chl-a 345 relative to the initial community (Fig. 4B; Table 2). Consistent with the patterns seen in the

346 EAC, Fucoxanthin:Chl-a increased in NFe and Mix bottles (and in the N treatment), which was

347 concomitant with a decline in haptophytes (Hexo-Fuco:Chl-a; Fig. 4D and F; Table 2). There

348 was a decrease in picoeukaryotes in the Mix treatment relative to unamended controls (Fig. 5D),

349 as well as a measurable increase in Prochlorococcus with NFe amendment (Fig. 5H).

350 Synechococcus showed little effect of nutrient amendment in the CCE but declined when all

351 nutrients were added together (p-value $<0.05$; Fig. 5F; Table 2). Similar to the EAC, there was

352 an overall increase in cell size of the CCE phototrophic assemblage into the micro size class with

353 NFe and Mix amendment (p-value < 0.05; Fig. 5B). The Mix addition caused the greatest shift in

354 cell size structure, decreasing the abundance of small cells by an order of magnitude (Fig. 5).

355 Similar to the EAC community, the largest shift in phototrophic community composition and 
356 structure was in the Mix relative to all other treatments (SIMPER, $\geq 55 \%$ dissimilarity), mainly

357 due to the decrease in Synechococcus and picoeukaryotes.

358 Nutrient-induced shifts in the heterotrophic community. Nutrient-induced changes in the

359 EAC bacterioplankton community were also detected by the end of the experiment (Figs. 5I, 6,

360 7). There was a significant (but relatively small) decrease in the relative abundance of sequences

361 matching SAR11 Surface 1 and SAR116 clades, and an increase in relative abundance of

362 Synechococcus with N, NFe, Mix addition, with the greatest dissimilarity in bacterial community

363 composition observed between the $\mathrm{t}_{0}$ and NFe treatments (SIMPER, $29 \%$ dissimilarity). These

364 shifts in SAR11, SAR116 and Synechococcus relative abundance contributed to 3, 2 and $2 \%$

365 dissimilarity between the $t_{0}$ and NFe treatments respectively (Fig.6; SIMPER). This pattern of

366 increasing Synechococcus sequence abundance was consistent with the patterns of

367 Synechococcus abundance revealed from flow cytometry (Fig. 5E). Within EAC nutrient

368 addition treatments, the greatest dissimilarity was observed between bacterioplankton

369 communities in the NFe and $\mathrm{Si}$ amendments (SIMPER, $29 \%$ dissimilarity). A relative decrease

370 in Synechococcus with $\mathrm{Si}$, and an increase in the SAR116 clade and Prochlorococcus,

371 contributed 3,2 and 2\% to the dissimilarity between NFe and Si treatments, respectively (Fig. 6;

372 SIMPER).

373 In the CCE bacterioplankton composition was distinct from the EAC in unamended controls

374 after 3 days (ANOSIM, Global R: 1.00, p-value $<0.01$; Fig. 7F), with the SAR116 clade and

375 Rhodobacteraceae more abundant in the CCE than in the EAC, and SAR11 surface clade and

376 Prochlorococcus less abundant (Fig. 6. Total heterotrophic bacterial abundance in the CCE

377 doubled after 3 days with $\mathrm{Si}$ and Mix addition, unlike the EAC community (Fig. 5I and J). 
378 However, there was no appreciable shift in bacterioplankton diversity between nutrient addition

379 treatments (Fig. 7E; ANOSIM, Global R: 0.14, p-value > 0.05).

380 Similar to the patterns observed in the overall bacterioplankton compositon, diazotroph diversity

381 in the EAC shifted following nutrient amendment (ANOSIM, Global R: 0.79, p-value =0.001;

382 Fig. 7G). Nutrient addition shifted the composition of diazotrophs from gamma-, beta-, and

383 delta-proteobacteria toward several Cluster 1 gamma-proteobacterial NifH sequences (NifH OTU

384 608, 2012 and 95), sharing $\geq 89 \%$ amino acid identity with Pseudomonas stutzeri (Moisander et

385 al. 2014, 2012), which comprised negligible proportions of initial EAC NifH sequences. Shifts in

386 the relative abundance of the three different gamma-proteobacterial NifH OTUs contributed to a

387 substantial proportion of the dissimilarity between diazotroph communities detected in EAC

388 nutrient treatments. For example, NifH OTU608 dominated NFe bottles, comprising up to $97 \%$

389 of $\mathrm{NifH}$ sequences and was responsible for $33 \%$ of the average dissimilarity between $\mathrm{t}_{0}$ and $\mathrm{NFe}$

390 (SIMPER, $83 \%$ total dissimilarity). In Si bottles, NifH OTU2012 represented up to $87 \%$ of NifH

391 sequences detected, and contributed $41 \%$ to the average dissimilarity between the $\mathrm{t}_{0}$ and $\mathrm{Si}$

392 bottles (SIMPER, $65 \%$ dissimilarity). Similarly NifH OTU95 comprised up to $89 \%$ of NifH

393 sequences in the Mix treatment and was responsible for $22 \%$ of the dissimilarity between the $t_{0}$

394 and diazotrophs in the Mix addition.

395 In contrast to $\mathrm{NifH}$ sequences retrieved from EAC nutrient treatments, the dominant $\mathrm{NifH}$ OTU 396 across CCE nutrient amendments was OTU2331, which shared $90 \%$ amino acid identity to the 397 genus Coraliomargarita of the Verrucomicrobia. In addition, sequences sharing $95 \% \mathrm{NifH}$ 398 amino acid identity with Trichodemsium erythraeum (OTU181) and Candidatus 399 Atelocyanobacterium thalassa (UCYN-A; OTU1321 and OTU50), were detected in the 400 unamended CCE diazotroph assemblages, but no such cyanobacterial NifH sequences were 
401 present in the EAC. Differences in the relative abundance of these cyanobacterial diazotrophs

402 were observed between treatments, such as an increase in OTU181 from a maximum of $15 \%$ in

403 the control to $62 \%$ in the $\mathrm{Si}$ treatment, there were also significant shifts in diazotroph

404 composition between nutrient addition treatments (Fig. 7H) (ANOSIM, Global R: 0.69, p-value

$405=0.004)$. Notably, there were no NifH sequences detected in the CCE Mix treatment.

406

407 Time-dependent response to nutrient amendment: subcellular to community-level. Daily

408 sampling of incubation bottles following nutrient amendment captured a cascade of effects at the

409 cellular, population and community level, indicating differences in the speed of response by

410 different microbes to nutrient resupply. Despite lower phytoplankton biomass, the EAC

411 community took up $\sim 10$ times more nitrate than the CCE community within the first $24 \mathrm{~h}$ (Fig.

$4128 \mathrm{~A}$ and $\mathrm{B}$ ). , Net nitrate uptake in the EAC (averaged over day 1 to 3) was greatest in the Mix

$413\left(2.98 \pm 0.88 \mu \mathrm{M} \mathrm{d}^{-1}\right)$, and NFe and $\mathrm{N}$ treatments $\left(\sim 2 \mu \mathrm{M} \mathrm{d}^{-1}\right)$, but was $<0.3 \mu \mathrm{M} \mathrm{d}^{-1}$ in all other

414 treatments. In the CCE, the level of nitrate uptake was an order of magnitude lower, with rates

415 ranging from 0.02 to $0.25 \mu \mathrm{M} \mathrm{d}^{-1}$ (in the control and Mix, respectively). Net phosphate uptake by

416 both communities was relatively constant across nutrient amendments $\left(\sim 0.1\right.$ and $\sim 0.01 \mu \mathrm{M} \mathrm{d}^{-1}$ in

417 the EAC and CCE, respectively), with the exception of 30\% higher rates in the EAC Mix

418 treatment (Fig. S3). Net silicate uptake rates in the EAC were greater than the CCE $(\sim 0.1$ vs

$419 \sim 0.05 \mu \mathrm{M} \mathrm{d}^{-1}$, respectively), with rates increasing significantly ( $\geq 6$ times) when Si was added

420 alone or with N, P and Fe (i.e., Mix treatment; Fig. S3). Total dissolved iron (TDFe)

421 concentrations at the end of the experiment were $0.38 \pm 0.07 \mathrm{nM}$ in the unamended EAC control

422 bottles, and $1.32 \pm 0.23 \mathrm{nM}$ in the CCE controls (Fig. S3), suggesting a strong Fe consumption

423 and thus a limited Fe potential contamination in the experiment (spikes were $10 \mathrm{nM}$ ). 
424 To illustrate the impact of nutrient amendment at the cellular, population and community level in

425 the EAC and CCE, Fig. 8 shows time-dependent responses to the $\mathrm{N}$ treatment. The cellular

426 pigment content (as estimated using flow cytometer fluorescence emission detected at red/orange

427 wavelengths, corresponding to Chl-a/phycoerythrin) of EAC phototrophs in the $\mathrm{N}$ treatment was

428 relatively constant over the first $48 \mathrm{~h}$, but then increased in both phycoerythrin-containing

429 prokaryotes and Chl-a-containing cells by $\mathrm{t}_{72}$ (Fig. 7C; Tables 2 and 3). In the CCE, $\mathrm{N}$ addition

430 caused rapid synthesis of Chl-a (but not phycoerythrin) in the first $24 \mathrm{~h}$. By day 3 however,

431 phycoerythrin-containing prokaryotes in the CCE had doubled their pigment content, in a

432 manner that was similar to the observations in the EAC (Fig. 7D).

433 The initial ranked order abundance of microbial populations (as determined flow cytometrically)

434 was different in the EAC and CCE and showed variable temporal dynamics. N amendment of the

435 EAC community resulted in a doubling of total bacteria abundance within the first $24 \mathrm{~h}$ (Fig.

$4368 \mathrm{E}$ ), but they then decreased to initial concentrations by $\mathrm{t}_{72}$. The abundance of all but the large

437 picoeukaryote population declined in the EAC under $\mathrm{N}$ amendment, resulting in overall negative

438 phototrophic growth over the three day experiment $\left(-0.153 \pm 0.016 \mathrm{~d}^{-1}\right.$; Table S2). In contrast,

439 the abundance of all CCE phototroph populations increased within the first $24 \mathrm{~h}$ following $\mathrm{N}$

440 amendment (Fig. 8D), and yielded significant positive growth during the experiment $(0.262 \pm$

$\left.4410.043 \mathrm{~d}^{-1}\right)$.

442 Nutrient amendment caused a minor decline in the maximum quantum yield of PSII $\left(\mathrm{F}_{\mathrm{V}} / \mathrm{F}_{\mathrm{M}}\right)$ in 443 the EAC microbial community with $\mathrm{N}$ addition ( $\mathrm{p}$-value $=0.013$; Table 2), but had no effect on

$444 \quad \mathrm{~F}_{\mathrm{V}} / \mathrm{F}_{\mathrm{M}}$ in the CCE community, remaining $>0.65$ in the unamended controls (Fig. 8A). The light 445 saturating irradiance $\mathrm{I}_{\mathrm{K}}$ was $\sim 50 \%$ lower in the EAC, reflecting the greater depth of the sampled 446 community (Table 1), and despite lower phytoplankton biomass, carbon fixation rates in 
447 unamended EAC bottles were higher than that of CCE controls (Fig. 8G and H). N amendment

448 of the EAC community lead to a significant increase in light utilisation efficiency $(\alpha)$ and light

449 saturated photosynthetic rate $\left(\mathrm{P}_{\max }\right)$ with no change in minimum saturating irradiance $\left(\mathrm{I}_{\mathrm{K}}\right)$

450 between the control and $\mathrm{N}$ enriched cells. There was however, a significant decline in $\mathrm{I}_{\mathrm{K}}$ in the

451 NFe treatment ( $p$-value $<0.05$ Table 2). In the CCE, there was a significant increase in $\alpha$ and $P_{\max }$

452 with both $\mathrm{N}$ and $\mathrm{NFe}$ addition, with $\mathrm{I}_{\mathrm{K}}$ lowest in the NFe treatment. There was a 1.7 times

453 increase in the maximum rate of primary productivity in the $\mathrm{N}$ amended treatment for the EAC

454 (p-value $<0.001$ ), compared with a 2.7 times increase in the CCE (p-values $<0.001$; Fig. 8G and

$455 \mathrm{H})$. Co-addition of NFe resulted in a decrease in PP in the EAC ( 0.4 fold change), but a 6.28 fold

456 increase in PP in the CCE. This suggests stronger limitation of primary productivity in the CCE,

457 with a greater proportional increase in $\mathrm{P}_{\max }$ with $\mathrm{NFe}$ compared to $\mathrm{N}$ addition.

\section{Discussion}

460 The intensification of western boundary currents in the global ocean (Wu et al. 2012) raises

461 significant questions about their impact on microbial composition and biogeochemical activity,

462 particularly in light of the potential for WBCs to promote meso-scale eddy formation (Mata et al.

463 2007) and induce nutrient upwelling (Roughan \& Middleton 2002). Here we show clear

464 differences in the vertical nutrient structure of a cyclonic cold-core eddy relative to adjacent

465 waters, and an increase in microbial diversity and size structure of an eddy assemblage relative to

466 an adjacent western boundary current, the EAC. Our results indicate that cyclonic eddies

467 increase delivery of $\mathrm{N}$ to the upper ocean but also increase the biological demand for Fe that is 
468 necessary to sustain the growth of large-celled phototrophs and potentially support the diversity

469 of diazotrophs over longer time-scales.

\section{Responses of microbes to nutrient amendment.}

471 Previous studies in the Tasman Sea region have determined that surface phytoplankton

472 communities are limited by N (Hassler et al. 2011; Hassler et al. 2014; Ellwood et al. 2013), and

473 that diazotrophs (cyanobacteria that are able to bypass nitrate limitation by fixing atmospheric N)

474 inhabit waters to $\sim 100 \mathrm{~m}$ following nutrient draw-down over the summer (Moisander et al.

475 2010). Our observations show that EAC phytoplankton sampled at $80 \mathrm{~m}$ below the surface are

476 also $\mathrm{N}$ limited, and that upwards displacement of isopycnal surfaces induced by a cyclonic eddy

477 introduces nutrients into the euphotic zone to alleviate potential N limitation (Fig. 4).

478 Phytoplankton in the CCE (sampled at $\sim 40 \mathrm{~m}$ ) were also limited by $\mathrm{N}$, but rates of carbon

479 fixation more than doubled under NFe relative to $\mathrm{N}$ amendment, likely due to the different

480 species composition underpinning primary productivity. In both water masses, a positive

481 response in $\mathrm{Chl}-\mathrm{a}$ was also seen with addition of $\mathrm{N}+\mathrm{Fe}+\mathrm{Si}+\mathrm{P}$, suggesting co-limitation by

482 multiple nutrients in both water masses, likely a result of different nutrient requirements by

483 different phototrophs. Uplift of $\mathrm{N}$ together with Fe and other nutrients would therefore increase

484 the rate of biomass production in the eddy as well as increase the relative abundance of diatoms,

485 both of which could act to increase export production relative to adjacent waters.

486 While the starting communities in the EAC and CCE were distinct, microbial phototrophs

487 showed similar responses to nutrient amendment in both water masses, with NFe addition to the

488 EAC resulting in phototrophs more similar to those in the initial CCE community (Fig. 7C).

489 Fucoxanthin containing cells (likely diatoms that contribute significantly to export production; 
490 Honjo et al. 1995) became more prevalent in NFe and Mix treatments, whereas haptophytes

491 clearly diminished under these amendments. Similarly, peridinin-containing dinoflagellates were

492 initially present in both communities, but their abundance declined with nutrient amendment,

493 becoming undetectable amongst other EAC microbes at the end of our experiment.

494 Prochlorococcus was an order of magnitude more abundant in the EAC relative to the CCE,

495 consistent with the warmer "tropical" signature of this western boundary current (Seymour et al.

496 2012), and declined in abundance in the Mix treatment. In the CCE samples, Prochlorococcus

497 similarly decreased in the Si and Mix treatments. Synechococcus had a positive response to

498 bottle enclosure but unlike other studies (Moisander et al. 2012), we found that its abundance

499 was similar in control and enriched treatments. Maximum net growth rates were observed in the

500 eddy NFe bottles for Prochlorococcus $\left(0.345 \pm 0.047 \mathrm{~d}^{-1}\right)$, small picoeukaryotes $(0.212 \pm 0.033$

$501 \mathrm{~d}^{-1}$ ) and large picoeukaryotes (i.e., nano-eukaryotes; $0.297 \pm 0.059 \mathrm{~d}^{-1}$ ), but for Synechococcus,

502 maximum growth was found in CCE controls $\left(0.324 \pm 0.047 \mathrm{~d}^{-1}\right.$, relative to $0.194 \pm 0.035 \mathrm{~d}^{-1}$

503 with NFe amendment).

504 Among the heterotrophic bacteria, initial EAC and CCE populations displayed similar abundance 505 and alpha-diversity, and nutrient amendment lead to compositional shifts in both water masses.

506 Addition of nitrate to the EAC community caused a doubling of total bacteria abundance within

507 the first $24 \mathrm{~h}$. Bacteria also became more abundant in the CCE community after 3 days within the

$508 \mathrm{Si}$ and Mix bottles. Elevated bacteria abundance is likely to have arisen through increased

509 dissolved organic matter (DOM) production by the resident community via several potential

510 mechanisms: (1) mortality and cell lysis; (2) elevated rates of DOM release due to nutrient

511 supplementation; and (3) altered microbial composition. While we did not measure rates of 
512 DOM production, our data certainly demonstrate coupling between autotrophs and heterotrophs,

513 just as in a previous study (Baltar et al. 2010).

514 Diazotroph relative abundance and diversity. Across the global ocean, the main supply of

515 nitrogen into surface waters is via transport from below the thermocline, but in many regions

516 significant amounts of new nitrogen may also be supplied via nitrogen fixation (Capone et al.

517 2005; La Roche \& Breitbarth 2005). Our molecular analyses revealed the presence of

518 heterotrophic gamma-proteobacterial diazotrophs in the sub-surface EAC microbial community,

519 whereas cyanobacterial diazotrophs (i.e., Trichodesmium and UCYN-A) were detected in the

520 CCE. Given the relatively high iron requirement of diazotrophs (Kustka et al., 2003), as well as

521 their low reliance on dissolved inorganic $\mathrm{N}$, we expected to see a divergent response of the

522 diazotrophs to nutrient amendment. Indeed, in the Mix bottles, diazotrophs became undetectable

523 in the CCE samples, and were clearly outcompeted by the eukaryote phototrophs. Nutrient

524 addition resulted in NifH OTU2331 becoming more prominent across CCE nutrient amendments.

525 This OTU shares $90 \%$ amino acid identity to the genus Coraliomargarita of the

526 Verrucomicrobia, and was not present amongst the EAC diazotrophs. In the EAC, nutrient

527 addition caused a shift from the mixed proteobacterial community observed at t0, to NifH

528 OTU608, NifH OTU2012 and NifH OTU95. These OTUs represent distinct taxa at the 95\%

529 sequence similarity level, yet share the same \% identity at the amino acid level, falling within the

530 same clade of Cluster 1 gamma-proteobacterial diazotrophs. The physiology or genome content

531 of these taxa remains completely unknown, but they seem to be abundant in warm, oligotrophic

532 surface waters globally (Langlois et al., 2005). In the southwestern Pacific, the abundance of this

533 group has been shown to be correlated to DOC concentration, and to increase with Fe and P

534 addition (Moisander et al., 2012). In contrast, the dominant diazotroph in the CCE was an OTU 
535 sharing $95 \%$ NifH amino acid identity with Trichodemsium erythraeum (OTU181) and OTUs

536 matching Candidatus Atelocyanobacterium thalassa (UCYN-A; OTU1321 and OTU50).

537 UCYN-A is the dominant diazotroph in the Coral Sea (source of the EAC) during the austral

538 spring (Messer et al., 2015), and is also relatively abundant in the western South Pacific

539 (Moisander et al., 2010). UCYN-A abundance has previously been shown to increase in response

540 to Fe and organic carbon additions (Moisander et al., 2012), while Fe has also been shown to

541 increase the rate of $\mathrm{N}_{2}$ fixation by UCYN-A (Krupke et al., 2015).

542 Our observations demonstrate the presence of heterotrophic $\mathrm{N}_{2}$-fixing organisms in sub-surface

543 waters with strong nitrate deficiency (but not necessarily low nitrate concentration; Fig. 2);

544 however, a remaining research need is to conduct $\mathrm{N}_{2}$-fixation rate measurements in conjunction

545 with diazotroph diversity assessment to verify whether this process represents a significant

546 source of new $\mathrm{N}$ within and outside eddies, and whether changes in $\mathrm{N}_{2}$-fixation are due to a shift

547 in diversity or a change in NifH expression.

548 Physiological responses to nutrient supply. At the cellular level, $\mathrm{N}$ addition caused rapid

549 pigment synthesis (doubling of normalised fluorescence per cell) in the CCE assemblage within

550 the first $24 \mathrm{~h}$ after amendment, indicating that nutrient uplift could initially cause 'greening' in

551 the absence of an increase in cellular biomass (Behrenfeld et al. 2015). By the end of our

552 experiments, both phycoerythrin and Chl-a quotas increased in both water masses with $\mathrm{N}$

553 amendment, concomitant with an increase in total Chl-a, suggesting both pigment synthesis and

554 biomass production contributed to elevated Chl-a. These observations are of obvious importance

555 for the accurate interpretation of satellite and other in situ Chl-a fluorescence data within meso-

556 scale eddy features. 
557 Photophysiological changes such as a decline in PSII turnover time, cross-sectional area and

558 increased electron transport rates have been detected upon relief of nutrient limitation (Milligan,

559 Aparicio \& Behrenfeld 2012). We detected minimal change in the photochemical efficiency

560 (maximum quantum yield of PSII) with nutrient amendment, but there were measureable

561 changes in the shape of the photosynthesis-irradiance (P-I) curve. Nitrate amendment of the EAC

562 community increased light utilisation efficiency and light saturated photosynthetic rates,

563 indicating increased photosynthetic electron transport and antenna size. Our flow cytometry data

564 suggest that this was likely due to increased chlorophyll quota rather than an increase in cross

565 sectional area (Fig. 7D). In the CCE community, the greatest change in carbon fixation (P-I)

566 parameters was measured in the NFe treatment, suggesting an increase in PSII units per cell

567 (detected via increased pigment quotas after $24 \mathrm{~h}$ ), as well as an increase in total photosynthetic

568 biomass, resulting in increased electron transport rates and light capturing capacity.

569 Nutrient uptake dynamics. Initial uptake rates of nitrate (i.e. within the first day) by the EAC

570 community were 10 times higher than in the CCE despite 3-fold lower phytoplankton biomass.

571 This is consistent with the opportunistic nutrient uptake strategies of phytoplankton in

572 oligotrophic habitats (McCarthy \& Goldman 1979) and the theory that fast growing algae (with

573 small cell size) are stimulated by short-term nutrient supply (Pederson \& Borum 1996).

574 However, it is unlikely that such high nutrient uptake rates would be sustained in the EAC,

575 largely because nutrient inputs (of the magnitude used in our experiments) are episodic and often

576 coincide with major physical disturbances such as cyclones (e.g. Law et al. 2011). A comparison

577 of the initial EAC and CCE communities suggests that prolonged nutrient inputs within cyclonic

578 eddies results in a shift toward larger cells which generally have greater capacity for nutrient

579 storage and higher nutrient requirements for growth (Litchman et al. 2007). 
580 Despite these potential experimental artefacts, the relative differences in nutrient demand

581 between treatments show that maximum net uptake rates in both water masses occurred when all

582 macronutrients were added together, compared to treatments which contained a surplus of N, P

583 or Si relative to other macronutrients and iron. Under $\mathrm{N}$ amendment, uptake ratios of $\mathrm{N}: \mathrm{P}$ in the

584 EAC were $\sim 20$ compared to $\sim 10$ in the CCE, and uptake ratios of N:Si were $\sim 10$ and 4 in the

585 EAC and CCE, respectively, but they were closer to Redfield ( $\mathrm{Si}: \mathrm{N}: \mathrm{Pi}=1: 1: 16)$ in the Mix

586 treatment (Fig. S2). This indicates that the vertical distribution of nutrients relative to one

587 another will regulate microbial responses to eddy-induced uplift, as has been shown by Bibby

588 and Moore (2011) with respect to N:Si in the sub-tropical north Atlantic and central Pacific near

589 Hawai'i.

\section{Conclusions}

591 Phytoplankton community structure plays an important role in the ecology and biogeochemistry

592 of pelagic ecosystems including the export of organic matter to the deep ocean and the 593 sequestration of carbon (Follows \& Dutkiewicz 2011; Karl et al. 2012). Here we show that 594 cyclonic eddies enhance primary production in this WBC region by delivering nitrate to the 595 upper ocean. The enhanced productivity was driven largely by an increase in the abundance of 596 diatoms, with a concomitant decline in the abundance of haptophytes and peridinin-containing 597 dinoflagellates.

598 This study confirms the low-nutrient low Chl-a status of the Eastern Australian Current (EAC) to 599 sub-surface depths of $\sim 80 \mathrm{~m}$, and provides the first evidence of $\mathrm{N}$ and Fe co-limitation in an 600 adjacent cyclonic eddy, demonstrating that such meso-scale features have the potential to 601 increase internal nutrient inputs into the upper ocean and thereby change microbial composition 
602 and nutrient demand. Importantly, eddies may provide a critical compensatory mechanism to 603 enrich the upper ocean and counteract increasing stratification occurring under climate change 604 (Matear et al. 2013). The divergent response of large phototrophs and diazotrophs in our nutrient

605

606

607

608

609

610

611

612

613

614

615

616

617

618

619

620

621

622

623

624

625

626

627

628

629

630

631

632 amendment experiments suggests that $\mathrm{N}_{2}$-fixing cyanobacteria and heterotrophic bacteria are an important functional group to include in biogeochemical models, whose abundance and diversity have been under-appreciated in this region until recently (Messer et al., 2015).

\section{Acknowledgements.}

We thank the officers and crew of the $R / V$ Southern Surveyor and the Bio-optics voyage participants, particularly Massimo Pernice (Instituto de Ciencias del Mar- Consejo Superior de Investigacion Cientifica, Spain) for assistance with sampling, Andrew Bowie for dissolved Fe flow injection analyses, as well as Jennifer Clark (University of Technology Sydney) for flow cytometry analyses.

\section{References}

Acosta Martinez V, Dowd SE, Sun Y, Allen V (2008) Tag-encoded pyrosequencing analysis of bacterial diversity in a single soil type as affected by management and land use. Soil Biology and Biochemistry. 40(11):2762-2770.

Altschul S, Gish W, Miller W, Myers E, Lipman D (1990) Basic local alignment search tool. Journal of Molecular Biology 215:403-410.

http://www.sciencedirect.com/science/article/pii/S0022283605803602 (Accessed December 13, 2013).

Baltar F, Arı'stegui J, Gasol JM, Lekunberri I, Herndl GJ (2010) Mesoscale eddies: hotspots of prokaryotic activity and differential community structure in the ocean. The ISME Journal 4: 975-988.

Barlow RG, Stuart V, Lutz V, Sessions H, Sathyendranath S, Platt T, Kyewalyanga M, Clementson L, Fukasawa M, Watanage S, Devred E (2007) Seasonal pigment patterns of surface phytoplankton in the subtropical southern hemisphere. Deep-Sea Research I 54:1687-1703.

Behrenfeld M (2011) Biology: Uncertain future for ocean algae. Nature Climate Change 1:33-34 doi:10.1038/nclimate1069. 
633 Behrenfeld MJ, O'Malley RT, Boss ES, Westberry TK, Graff JR, Halsey KH, Milligan AJ, 634 Siegel DA and Brown TB (2015) Revaluating ocen warming impacts on global phytoplankton. 635 Nature Climate Change doi: 10.1038/NCLIMATE2838.

636 Bibby TS, Gorbunov MY, Wyman KW, Falkowski PG (2008) Photosynthetic community 637 responses to upwelling in mesoscale eddies in the subtropical North Atlantic and Pacific Oceans. 638 Deep-Sea Research II 55: 1310-1320.

639 Bibby TS, Moore CM (2011) Silicate:nitrate ratios of upwelled waters control the phytoplankton 640 community sustained by mesoscale eddies in sub-tropical North Atlantic and Pacific.

641 Biogeosciences 8: 657-666.

642 Brzezinski MA, Nelson DM (1989). Seasonal changes in the silicon cycle within a Gulf Stream 643 warm-core ring. Deep-Sea Research 36: 1009-1023.

644 Capone DG, Burns JA, Montoya JP, Subramaniam A, Mahaffey C, Gunderson T, Michaels AF, 645 Carpenter EJ. (2005) Nitrogen fixation by Trichodesmium spp.: An important source of new 646 nitrogen to the tropical and subtropical North Atlantic Ocean. Global Biogeochemical Cycles 647 19(2) GB2024

648 Caporaso J, Kuczynski J, Stombaugh J, Bittinger K, Bushman F, Costello EK, et al. (2010). 649 QIIME allows analysis of high-throughput community sequencing data. Nature Methods 7:335650 336. http://dx.doi.org/10.1038/nmeth0510-335 (Accessed December 7, 2013).

651 Chelton DB, Schlax MG, Samelson RM (2011) Global observations of nonlinear mesoscale 652 eddies. Progress in Oceanography 91:167-216.

653 Clarke K (1993). Non-parametric multivariate analyses of changes in community structure. 654 Australian Journal of Ecology 18:117-143. http://onlinelibrary.wiley.com/doi/10.1111/j.1442655 9993.1993.tb00438.x/full (Accessed January 13, 2014).

656 Clarke K, Warwick R (2001) Change in marine communities: an approach to statistical analysis 657 and interpretation 2nd Edition. PRIMER-E Ltd: Plymouth

658 http://www.opengrey.eu/item/display/10068/595716 (Accessed January 14, 2014).

659 Cowley R, Critchley G, Eriksen R, Latham V, Plaschke R, Rayner M, Terhell D (1999) CSIRO

660 Marine Laboratories Report 236 Hydrochemistry Operations Manual. Technical report, CSIRO 661 Marine Laboratories, Hobart, Australia.

662 Deutsch C, Weber T (2012) Nutrient Ratios as a Tracer and Driver of Ocean Biogeochemistry 663 Annual Review of Marine Science 4:113-41.

664 Doblin MA, Ralph PJ, Petrou KL, Shelly K, Westwood K, van den Enden R, Wright S, Griffiths 665 B (2011) Diel variation of chl-a fluorescence, phytoplankton pigments and productivity in the 666 Sub-Antarctic Zone. Deep Sea Research II: Topical studies in oceanography 58:2189-2199.

667 Dowd SE, Callaway TR, Wolcott RD, Sun Y, McKeehan T, Hagevoort RG, et al. (2008)

668 Evaluation of the bacterial diversity in the feces of cattle using 16S rDNA bacterial tag-encoded 
669

670

671

672

673

674

675

676

677

678

679

680

681

682

683

684

685

686

687

688

689

690

691

692

693

694

695

696

697

698

699

700

701

702

703

704

FLX amplicon pyrosequencing (bTEFAP). BMC Microbiology 8:125.

http://www.pubmedcentral.nih.gov/articlerender.fcgi?artid=2515157\&tool=pmcentrez\&renderty pe $=$ abstract (Accessed January 23, 2014).

Edgar RC (2010) Search and clustering orders of magnitude faster than BLAST. Bioinformatics 26:2460-2461. http://www.ncbi.nlm.nih.gov/pubmed/20709691 (Accessed November 7, 2013).

Ellwood MJ, Law CS, Hall, J., Boyd PW (2013) Relationships between nutrient stocks and inventories and phytoplankton physiological status along an oligotrophioc meridional transect in the Tasman Sea. Deep-Sea Research I 72:102-120.

Everett JD, Baird ME, Oke PR, Suthers IM (2012) An Avenue of Eddies: Quantifying the biophysical properties of mesoscale eddies in the Tasman Sea. Geophysical Research Letters 39: L16608 doi:10.1029/2012GL053091.

Everett JD, Baird ME, Roughan M, Suthers IM, Doblin MA (2014) Relative impact of seasonal and oceanographic drivers of surface chlorophyll-a along a western boundary current. Progress in Oceanography 120:340-351.

Farnelid H, Andersson AF, Bertilsson S, Al-Soud WA, Hansen LH, Sørensen S, et al. (2011) Nitrogenase gene amplicons from global marine surface waters are dominated by genes of noncyanobacteria. PLoS One 6:e19223.

http://www.pubmedcentral.nih.gov/articlerender.fcgi?artid=3084785\&tool=pmcentrez\&renderty pe=abstract (Accessed March 14, 2013).

Farnelid H, Bentzon-Tilia M, Andersson AF, Bertilsson S, Jost G, Labrenz M, et al. (2013). Active nitrogen-fixing heterotrophic bacteria at and below the chemocline of the central Baltic Sea. The ISME Journal 7:1413-1423.

Fish JA, Chai B, Wang Q, Sun Y, Brown CT, Tiedje JM, et al. (2013) FunGene: the functional gene pipeline and repository. Frontiers of Microbiology 4:291.

http://www.pubmedcentral.nih.gov/articlerender.fcgi?artid=3787254\&tool=pmcentrez\&renderty pe $=$ abstract (Accessed February 5, 2014).

Foldager Pedersen M, Borum J (1996) Nutrient control of algal growth in estuarine waters. Nutrient limitation and the importance of nitrogen requirements and nitrogen storage among phytoplankton and species of macroalgae. Marine Ecology Progress Series 142:261-272.

Follows MJ, Dutkiewicz S, Grant S, Chisholm SW (2007) Emergent biogeography of microbial communities in a model ocean. Science 315:1843-1846.

Follows MJ, Dutkiewicz S (2011) Modeling Diverse Communities of Marine Microbes. Annual Review of Marine Science 3:427-451.

Gasol JM, Del Giorgio PA (2000) Using flow cytometry for counting natural planktonic bacteria and understanding the structure of planktonic bacterial communities. Scientifica Marina 64: $197-224$ 
705

706

707

708

709

710

711

712

713

714

715

716

717

718

719

720

721

722

723

724

725

726

727

728

729

730

731

732

733

734

735

736

737

738

739

740

741

Gaube P, McGillicuddy DJ Jr, Chelton DB, Behrenfeld MJ, Strutton PG (2014) Regional variations in the influence of mesoscale eddies on near-surface chlorophyll. Journal of Geophysical Research Oceans 119:8195-8220.

Hagino K, Onuma R, Kawachi M, Horiguchi T (2013) Discovery of an Endosymbiotic NitrogenFixing Cyanobacterium UCYN-A in Braarudosphaera bigelowii (Prymnesiophyceae). PLoS ONE 8: e81749. doi:10.1371/journal.pone.0081749

Hassler C, Djajadikarta RJ, Doblin MA, Everett JD, Thompson P (2011) Characterisation of water masses and nutrient limitation of phytoplankton in the separation zone of the East Australian Current in spring 2008. Deep Sea Research II, special issue on East Australian Current. 58:664-677.

Hassler CS, Ridgway K, Bowie AR, Butler ECV, Clementson L, Doblin MA, Ralph P, Law CS, Davies DM, van der Merwe P, Watson R, Ellwood, MJ (2014) Primary productivity induced by Iron and Nitrogen in the Tasman Sea-An overview of the PINTS expedition. Marine and Freshwater Research 65:517-537.

Honjo S, Dymond J, Collier R, Manganini SJ (1995) Export production of particles to the interior of the equatorial Pacific Ocean during the 1992 EqPac experiment. Deep Sea Research II 42:831-870.

Hood RR, Laws EA, Armstrong RA, Bates NR, Brown CW, Carlson CA, Chai F, Doney SC, Falkowski PG, Feely RA, Friedrichs MAM, Landry MR, Moore KJ, Nelson DM, Richardson TL, Salihoglu B, Schartau M, Toole DA, Wiggert JD (2006) Pelagic functional group modeling: Progress, challenges and prospects. Deep-Sea Research Part II-Topical Studies in Oceanography 53:459-512.

Karl DM, Church MJ, Doreb JE, Letelier RM and Mahaffey C (2012) Predictable and efficient carbon sequestration in the North Pacific Ocean supported by symbiotic nitrogen fixation. Procedings National Academy Science 109:1842-1849.

Kustka AS, Sañudo-Wilhelmy S, Carpenter EJ, Capone DG, Raven, JA (2003) A revised estimate of the iron efficiency of nitrogen fixation with special reference to the marine cyanobacterium Trichodesmium spp. (cyanophyta). Journal of Phycology 39:12-25.

Krupke A, Mohr W, LaRoche J, Fuchs BM, Amann RI, Kuypers MM (2015) The effect of nutrients on carbon and nitrogen fixation by the UCYN-A-haptophyte symbiosis. ISME J. 9:1635-47.La Roche J, Breitbarth E (2005) Importance of diazotrophs as a source of new nitrogen in the ocean. Journal of Sea Research 53:67-69.

Langlois RJ, LaRoche J, Raab PA (2005) Diazotrophic Diversity and Distribution in the Tropical and Subtropical Atlantic Ocean. Applied and Environmental Microbiology 71:7910-7919.

Law CS, Woodward EMS, Ellwood MJ, Marriner A, Bury SJ, Safi KA (2011) Response of surface nutrient inventories and nitrogen fixation to a tropical cyclone in the southwest Pacific. Limnology and Oceanography 56:1372-1385. 
755
Liu H, Probert I, Uitz J, Claustre H, Aris-Brosou S, Frada M, Not F, de Vargas C (2009) Extreme diversity in noncalcifying haptophytes explains a major pigment paradox in open oceans. Proceedings of the National Academy of Science 106:12803-12808.

Litchman E, Klausmeier CA, Schofield OM, Falkowski PG (2007) The role of functional traits and trade-offs in structuring phytoplankton communities: scaling from cellular to ecosystem level. Ecology Letters 10:1170-1181.

Marie D, Partensky F, Jacquet S, Vaulot D (1997) Enumeration and cell cycle analysis of natural populations of marine picoplankton by flow cytometry using the nucleic acid stain SYBR Green I. Applied Environmental Microbiology 63:186-193.

Martin JH, Gordon RM and Fizwater SE (1991) The case for iron. Limnology and Oceanography 36:1793-1802.

Mata MM, Wijffels S, Tomczak M, Church JA (2007) Eddy shedding and energy conversions in the East Australian Current. Journal of Geophysical Research 111: C09034, doi10,1029/2006JC003592.

Matear RJ, Chamberlain MA, Sun C, Feng M (2013) Climate change projection of the Tasman Sea from an Eddy-resolving Ocean Model. Journal of Geophysical Research Oceans 118: 29612976.

McCarthy JJ, Goldman JC (1979) Nitrogenous nutrition of marine phytoplankton in nutrientdepleted waters. Science 203:670-672.

McGillicuddy DJ Jr (2016) Mechanisms of physical-biological-biogeochemical interaction at the oceanic mesoscale. Annual Review of Marine Science 8:13.1-13.36.

McGillicuddy DJ Jr, Robinson AR, Siegel DA, Jannasch HW, Johnson R, et al. (1998) Influence of mesoscale eddies on new production in the Sargasso Sea. Nature 394:263-265.

Messer LF, Mahaffey C, Robinson C, Jeffries TC, Baker KG, Bibiloni Isaksson J, Ostrowski M, Doblin MA, Brown MV, Seymour JR (2015) High levels of heterogeneity in diazotroph diversity and activity within a putative hotspot for marine nitrogen fixation. The ISME Journal, doi:10.1038/ismej.2015.205.

Milligan AJ, Aparicio UA, Behrenfeld MJ (2012) Fluorescence and nonphotochemical quenching responses to simulated vertical mixing in the marine diatom Thalassiosira weissflogii. Marine Ecology Progress Series 448:67-78.

Moisander PH, Serros T, Paerl RW, Beinart R, Zehr JP (2014) Gammaproteobacterial diazotrophs and nifH gene expression in surface waters of the South Pacific Ocean. The ISME Journal 8:1962-1973.

Moisander PH, Zhang R, Boyle E, Hewson I, Montoya JP, Zehr JP (2012) Analogous nutrient limitations in unicellular diazotrophs and Prochlorococcus in the South Pacific Ocean. The ISME Journal 6:733-44. 
780 Moisander PH, Beinart RA, Hewson I, White AE, Johnson KS, Carlson CA, Montoya JP, Zehr 781 JP (2010) Unicellular cyanobacterial distributions broaden the oceanic N2 fixation domain.

782 Science 327:1512-1514.

783 Nelson DM, McCarthy JJ, Joyce TM, Ducklow HW (1989) Enhanced near-surface nutrient 784 availability and new production resulting from the frictional decay of a Gulf Stream warm-core 785 ring. Deep-Sea Research A 36:705-714.

786 Moore CM, Mills MM, Arrigo KR, Berman-Frank I, Bopp L, Boyd PW, Galbraith ED, Geider 787 RJ, Guieu C, Jaccard SL, Jickells RJ, La Roche J et al. (2013) Processes and patterns of oceanic 788 nutrient limitation. Nature Geoscience 6:701-710.

789

790

791

792

793

794

795

796

797

798

799

800

801

802

803

804

805

806

807

808

809

810

811

812

813

814

815
Platt T, Gallegos CL, Harrison WG (1980) Photoinhibition of photosynthesis in natural assemblages of marine phytoplankton. Journal of Marine Research 38:687-701.

Quast C, Pruesse E, Yilmaz P, Gerken J, Schweer T, Yarza P, et al. (2013) The SILVA ribosomal RNA gene database project: improved data processing and web-based tools. Nucleic Acids Research 41:D590-6.

http://www.pubmedcentral.nih.gov/articlerender.fcgi?artid=3531112\&tool=pmcentrez\&renderty pe $=$ abstract (Accessed November 8, 2013).

Ridame C, Le Moal M, Guieu C, Ternon E, Biegala IC, L'Helguen S, et al. (2011) Nutrient control of $\mathrm{N}_{2}$ fixation in the oligotrophic Mediterranean Sea and the impact of Saharan dust events. Biogeosciences 8:2773-2783. http://www.biogeosciences.net/8/2773/2011/ (Accessed March 6, 2014).

Ridgway K, Godfrey J (1997) Seasonal cycle of the East Australian Current. Journal of Geophysical Research 102:22,921-22,936.

Roughan M, Middleton J (2002) A comparison of observed upwelling mechanisms off the east coast of Australia. Continental Shelf Research 22:2551-2572.

Schreiber U (2004) Pulse-Amplitude-Modulation (PAM) fluorometry and saturation pulse method: an overview. In: Papageorgiou G, Govindjee (eds) Chlorophyll a fluorescence: a signature of photosynthesis. Springer. Dordrecht pp 279-319.

Seymour JR, Seuront L, Mitchell JG (2007) Microscale gradients of planktonic microbial communities above the sediment surface in a mangrove estuary. Estuarine, Coastal and Shelf Science 73:651-666.

Seymour JR, Doblin MA, Jeffries TC, Brown MV, Newton K, Ralph PJ, Baird M, Mitchell JG (2012) Contrasting microbial assemblages in adjacent water-masses associated with the East Australian Current. Environmental Microbiology Reports 4:548-555.

Turk-Kubo KA, Achilles KM, Serros TRC, Ochiai M, Montoya JP, Zehr JP (2012) Nitrogenase (nifH) gene expression in diazotrophic cyanobacteria in the Tropical North Atlantic in response to nutrient amendments. Frontiers of Microbiology 3:386-403. 
816 http://www.pubmedcentral.nih.gov/articlerender.fcgi?artid=3487379\&tool=pmcentrez\&renderty $817 \mathrm{pe}=$ abstract (Accessed November 12, 2012).

818 Uitz J, Huot Y, Bruyant G, Babin M, Claustre H (2008) Relating phytoplankton

819 photophysiological properties to community structure on large scales. Limnology and

820 Oceanography 53:614-630.

821 Waite AM, Pesant S, Griffin DA, Thompson PA, Holl CM (2007) Oceanography, primary 822 production and dissolved inorganic nitrogen uptake in two Leeuwin Current eddies. Deep-Sea

823 Research II 54:981-1002.

824 Wang Q, Quensen J, Fish J, Lee T, Sun Y, Tiedje J, et al. (2013) Ecological patterns of nifH 825 genes in four terrestrial climatic zones explored with targeted metagenomics using FrameBot, a 826 new informatics tool. MBio 4:e00592-13. http://mbio.asm.org/content/4/5/e00592-13.short 827 (Accessed March 6, 2014).

828 Wu L, Cai W, Zhang L, Nakamura H, Timmermann A, Joyce T, McPhaden MJ, Alexander M, 829 Qiu B, Visbeck M, Chang P, Giese B (2012) Enhanced warming over the global subtropical 830 western boundary currents. Nature Climate Change 2:161-166.

831 Zehr J, Jenkins B, Short S, Steward G (2003) Nitrogenase gene diversity and microbial 832 community structure: a cross system comparison. Environmental Microbiology 5:539-554. 833 http://onlinelibrary.wiley.com/doi/10.1046/j.1462-2920.2003.00451.x/full (Accessed April 5, 834 2013).

Zehr J, McReynolds L (1989) Use of degenerate oligonucleotides for amplification of the nifH 837 Microbiology 55:2522-2526.

838 Zehr J, Turner P (2001) Nitrogen fixation: Nitrogenase genes and gene expression. Methods 839 Microbiology 30:271-285.

840 Zehr JP, Mellon MT, Hiorns WD (1997) Phylogeny of cyanobacterial nifH genes: evolutionary 841 implications and potential applications to natural assemblages. Microbiology 143:1443-1450. 
843 Tables

844 Table 1: Starting conditions for nutrient amendment experiments in the East Australian Current 845 (EAC) and a cyclonic cold core eddy (CCE). Note that sampling depths targeted the chlorophyll846 a fluorescence maximum (Fmax), which was deeper in the EAC than the CCE.

\begin{tabular}{|l|l|l|}
\hline & EAC & CCE \\
\hline Location & $29.14817^{\circ} \mathrm{S}, 154.31495^{\circ} \mathrm{E}$ & $32.35217^{\circ} \mathrm{S}, 153.58112^{\circ} \mathrm{E}$ \\
\hline Bottom depth $(\mathrm{m})$ & 3279 & 4632 \\
\hline Sampling depth $($ Fmax, $\mathrm{m})$ & 80 & 41 \\
\hline Temperature $\left({ }^{\circ} \mathrm{C}\right)$ & 21.08 & 21.31 \\
\hline Salinity & 35.52 & 35.49 \\
\hline Ammonium $(\mu \mathrm{M})$ & $0.07 \pm 0.02$ & $0.16 \pm 0.01^{*}$ \\
\hline Nitrate $(\mu \mathrm{M})$ & $0.26 \pm 0.24$ & $0.14 \pm 0.02$ \\
\hline Phosphate $(\mu \mathrm{M})$ & $0.12 \pm 0.02$ & $0.11 \pm 0.01$ \\
\hline Silicate $(\mu \mathrm{M})$ & $0.84 \pm 0.03$ & $0.52 \pm 0.01$ \\
\hline $\begin{array}{l}\text { Total dissolved iron }(\mathrm{TDFe}) \text { in } \\
\text { controls at t72 }(\mathrm{nM})\end{array}$ & $0.38 \pm 0.07$ & $1.32 \pm 0.23$ \\
\hline Chlorophyll-a $\left(\mu \mathrm{g} \mathrm{L}{ }^{-1}\right)$ & $0.106 \pm 0.008$ & $0.336 \pm 0.041$ \\
\hline
\end{tabular}

*analytical replicates from same CTD cast, not separate casts as for EAC $(n=2)$ 
850 Table 2: Effect of experimental manipulation on microbial assemblages in the East Australian 851 Current (EAC) and a cyclonic cold core eddy (CCE) as shown by comparison of $t_{0}$ with $t_{72}$ no 852 amendment contol, as well as $t_{72}$ nutrient amendments relative to controls. Treatments include $853 \mathrm{NO}_{3}\left(10 \mu \mathrm{M}\right.$ nitrate final concentration), $\mathrm{NO}_{3}+\mathrm{Fe}(10 \mu \mathrm{M}$ nitrate and $1 \mathrm{nM} \mathrm{Fe}$ final 854 concentration), $\mathrm{Si}(10 \mu \mathrm{M}$ final concentration), and $\mathrm{Mix}(\mathrm{N}+\mathrm{Si}+\mathrm{P}+\mathrm{Fe} ; 10 \mathrm{~N}: 10 \mathrm{Si}: 0.625 \mathrm{P} \mu \mathrm{M}$ in 855 Redfield proportions and $1 \mathrm{nM}$ Fe respectively). ++ strong positive difference, $\mathrm{P}<0.01 ;+$ 856 positive difference, $\mathrm{P}<0.05$; --strong negative difference, $\mathrm{P}<0.01$; - negative difference, $\mathrm{P}<0.05$; blank cells: no significant difference; nd: not detected; shaded cells: no measurement.

\begin{tabular}{|c|c|c|c|c|c|c|c|c|c|c|}
\hline \multirow[t]{3}{*}{ Parameter } & \multirow{2}{*}{\multicolumn{2}{|c|}{$\begin{array}{c}\text { Comparison } \\
\text { of } \mathrm{t}_{0} \text { versus } \\
\mathrm{t}_{72} \text { control }\end{array}$}} & \multicolumn{8}{|c|}{$\begin{array}{c}\text { Comparison of } \mathrm{t}_{72} \text { nutrient amendments } \\
\text { versus } \mathrm{t}_{72} \text { control }\end{array}$} \\
\hline & & & \multicolumn{2}{|l|}{$\mathrm{NO}_{3}$} & \multicolumn{2}{|c|}{$\mathrm{NO}_{3}+\mathrm{Fe}$} & \multicolumn{2}{|c|}{$\mathrm{Si}$} & \multicolumn{2}{|l|}{ Mix } \\
\hline & EAC & $\mathrm{CCE}$ & EAC & $\mathrm{CCE}$ & EAC & $\mathrm{CCE}$ & EAC & $\mathrm{CCE}$ & EAC & $\mathrm{CCE}$ \\
\hline Chlorophyll a & & - & + & + & + & + & & & + & + \\
\hline Fucoxanthin:Chl a & & & & + & + & + & & & + & + \\
\hline Hex-Fuco:Chl a & - & & & & - & - & & & & \\
\hline Peridinin:chl a & nd & & nd & - & nd & - & nd & - & & \\
\hline $\begin{array}{ll}\text { Cell abundance* } \\
-\quad \text { Total pico and nano } \\
\text { - } & \text { Prochlote } \\
- & \text { Synechococcus } \\
- & \text { Picoeukaryote } \\
- & \text { Nanoeukaryote } \\
- & \text { Bacteria }\end{array}$ & $\begin{array}{l}-- \\
+\end{array}$ & + & -- & & & + & --- & ++ & $\begin{array}{l}-- \\
--\end{array}$ & $\begin{array}{l}-- \\
++\end{array}$ \\
\hline $\mathrm{F}_{\mathrm{V}} / \mathrm{F}_{\mathrm{M}}$ & & & - & & & & & & & \\
\hline Chl-a fluorescence/cell & -- & & ++ & ++ & ++ & -- & & -- & & -- \\
\hline $\begin{array}{l}\text { Phycoerythrin } \\
\text { fluorescence/cell }\end{array}$ & & & ++ & & ++ & & & & & \\
\hline Primary production & + & & ++ & ++ & -- & ++ & & & & \\
\hline alpha & & & & ++ & & ++ & & & & \\
\hline $\mathrm{Ik}$ & & & & & -- & ++ & & & & \\
\hline $\begin{array}{ll}\text { Growth rate } \\
- & \text { Total } \\
- & \text { Prochlorococcus } \\
\text { - } & \text { Synechococcus } \\
- & \text { Picoeukaryote } \\
- & \text { Nanoeukaryote } \\
- & \text { Bacteria }\end{array}$ & & & $\begin{array}{l}-- \\
--\end{array}$ & & & + & -- & ++ & \begin{tabular}{|l}
- \\
-- \\
--
\end{tabular} & ++ \\
\hline
\end{tabular}



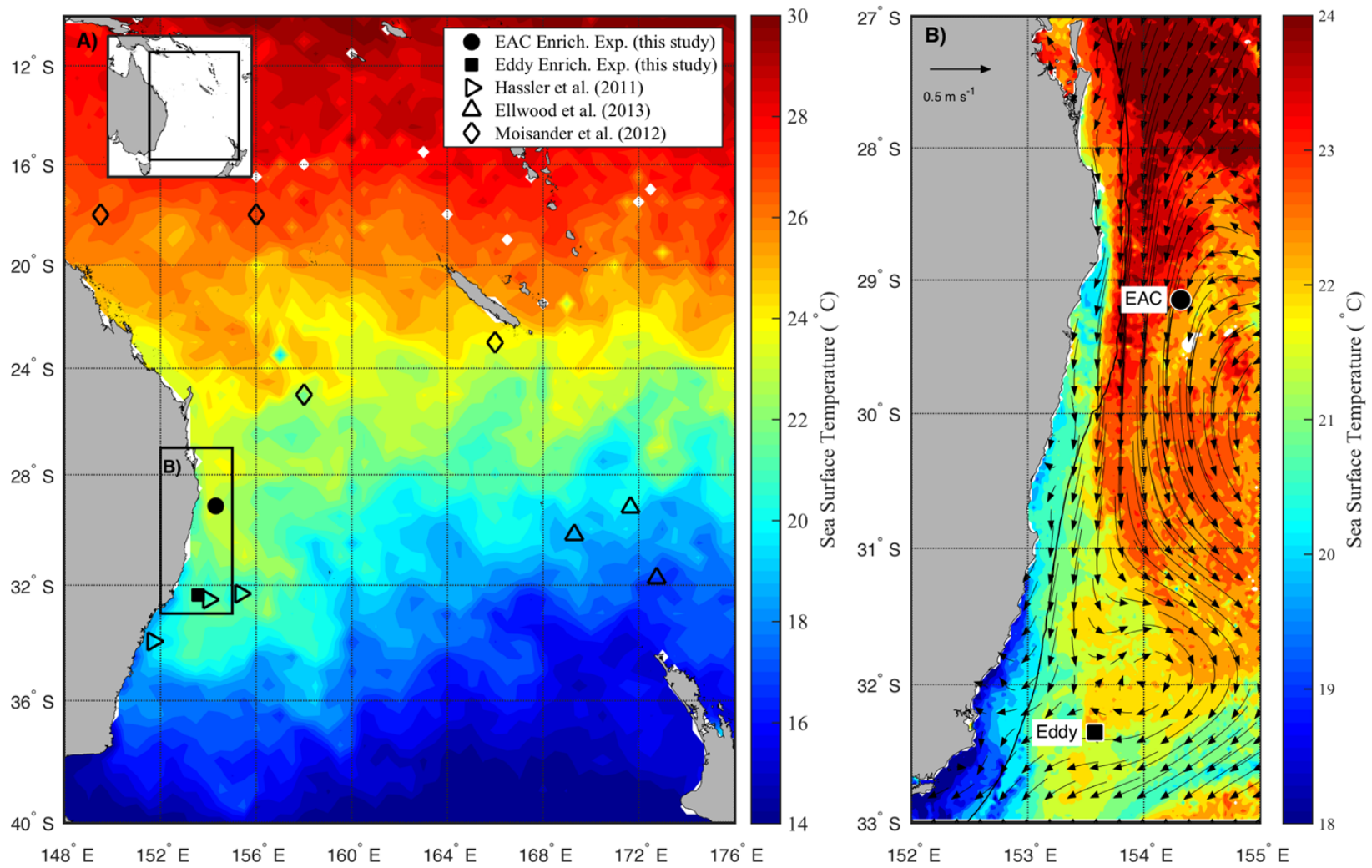

1. Study area. (A) Average sea surface temperature (SST) for October 2010 in the Tasman Sea, eastern Australia. The location of previous nutrient amendment studies are shown with symbols. The black box is the domain for the current study. (B) Average SST (20$25^{\text {th }}$ October 2010) of the study domain during the voyage, showing location of sampling sites. The black line shows $200 \mathrm{~m}$ isobath, which approximates the continental shelf edge. Geostrophic velocities, estimated from sea-level anomaly are shown as arrows $\left(20^{\text {th }}\right.$ October 2010). 

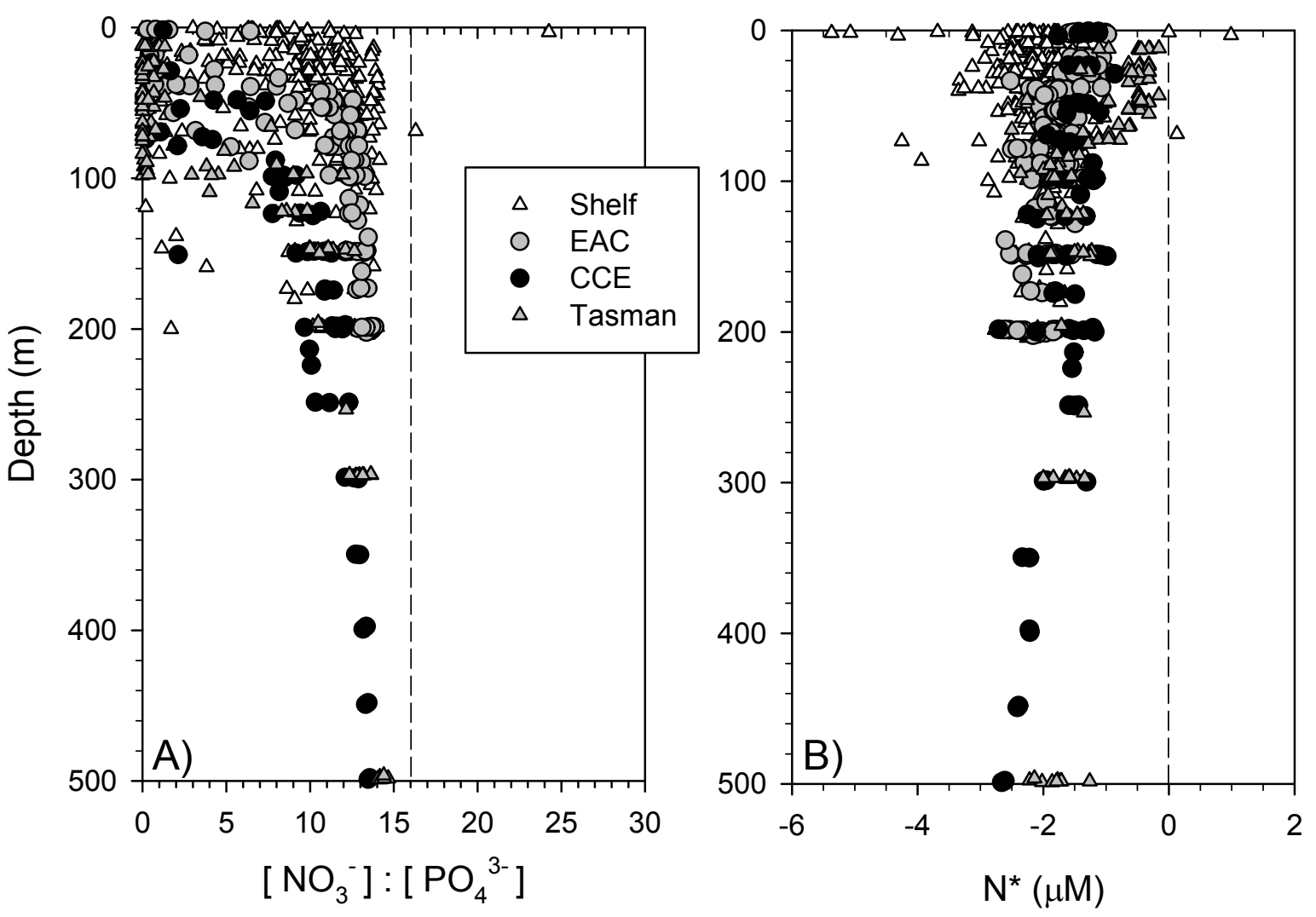

2. Dissolved nitrogen pool relative to phosphorus. The ratio of dissolved nitrate and phosphate (A) and nitrate deficit $\left(\mathrm{N}^{*}=\left[\mathrm{NO}_{3}{ }^{-}\right]-16\left[\mathrm{PO}_{4}{ }^{3-}\right]\right)(\mathrm{B})$ in waters of the study domain, including the continental shelf (white triangles), East Australian Current (EAC; grey circles), cyclonic cold-core eddy (CCE; black circles) and Tasman Sea (grey triangles). 


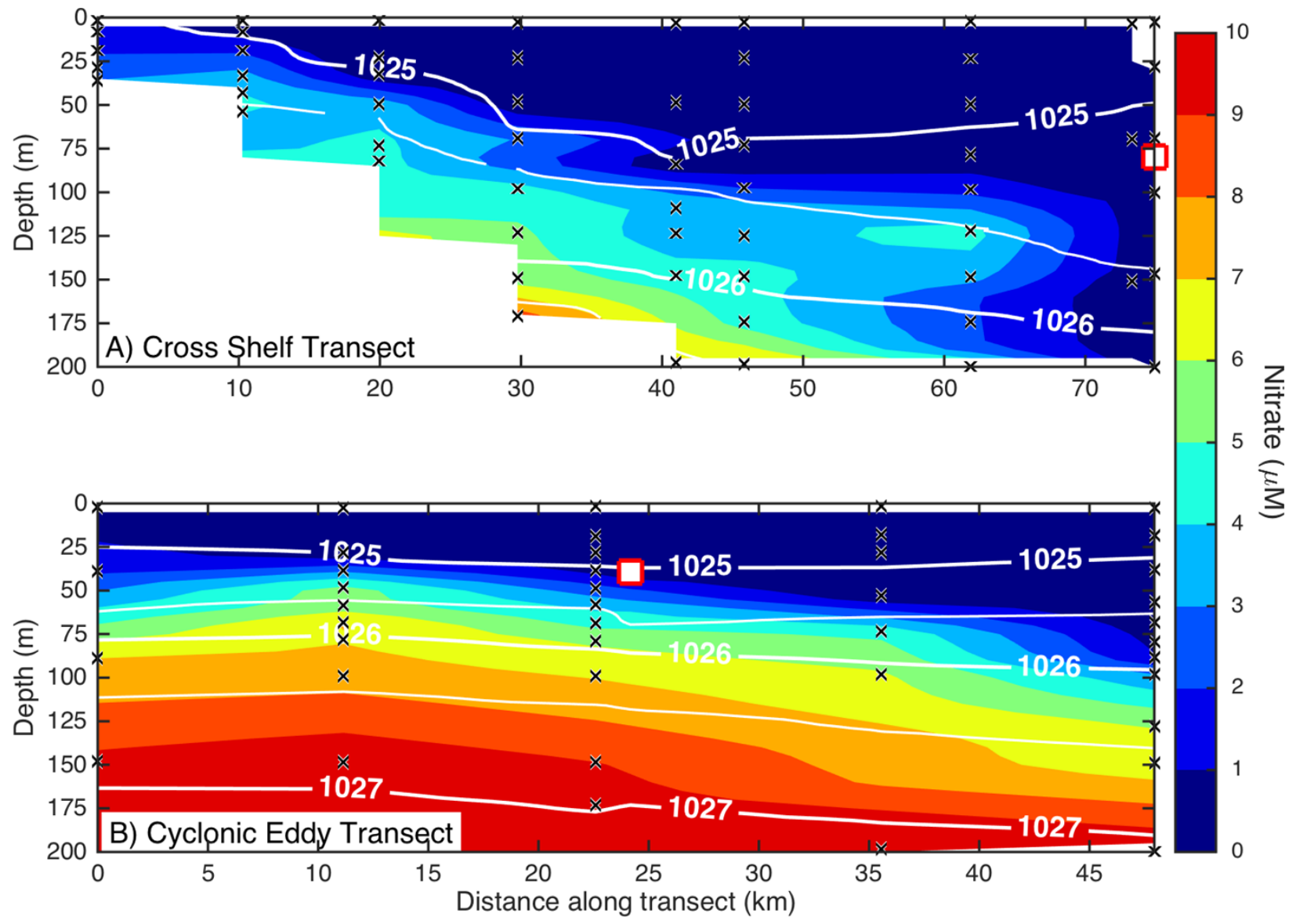

3. Eddy influence on vertical nutrient distribution. The distribution of dissolved nitrate (A) across the continental shelf to the East Australian Current, and (B) across the sampled cyclonic cold-core eddy. The white contours indicate seawater density, and the black crosses show the sampling locations for nitrate. The white squares indicate the water sampling locations for the nutrient amendment experiments. 

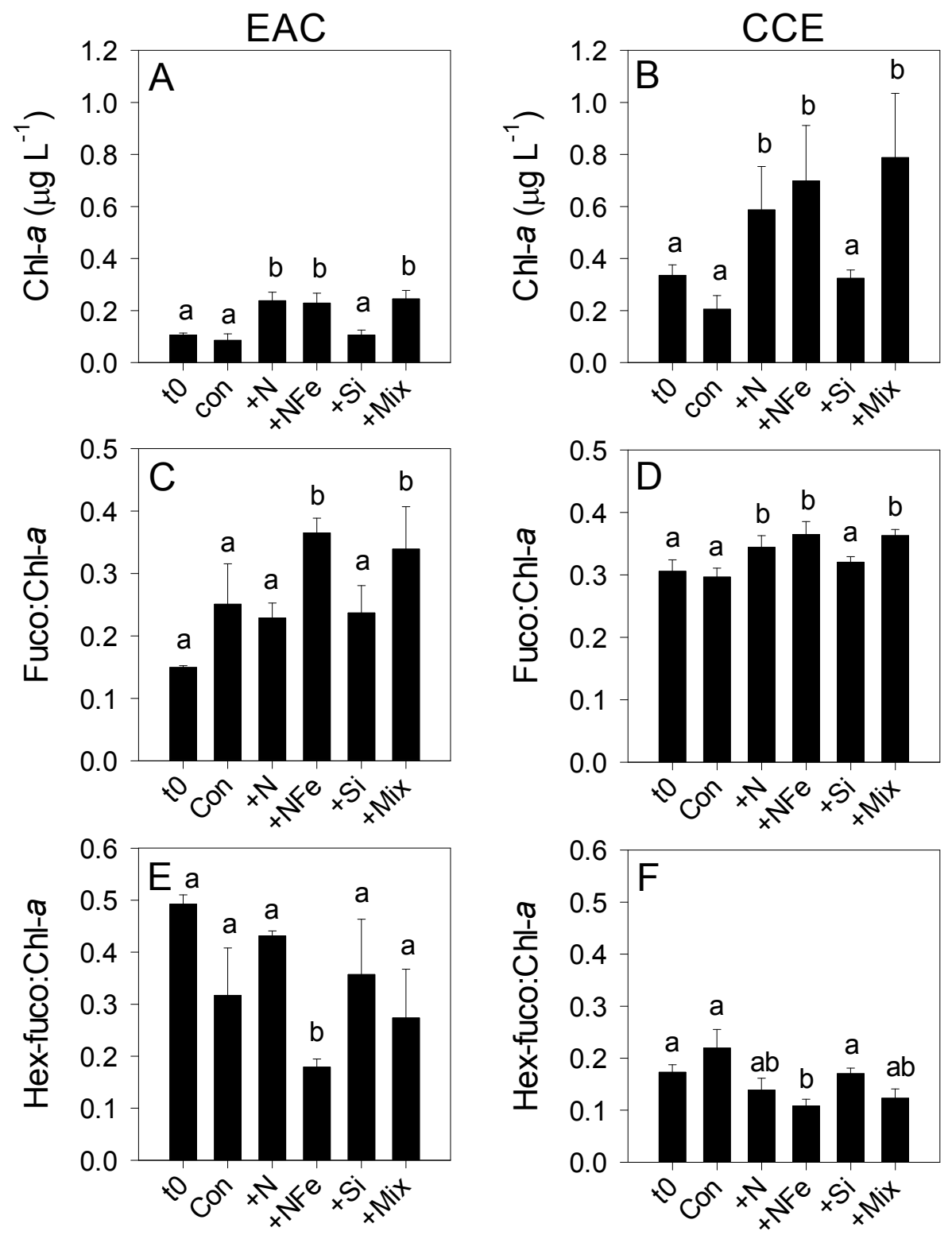

4. Phototrophic responses to nutrient amendment. Total Chl-a (monovinyl + divinyl), ratio of fucoxanthin to Chl-a and ratio of hex-fucoxanthin to Chl-a in the EAC (A, C and $\mathrm{E}$, respecively) and $\mathrm{CCE}(\mathrm{B}, \mathrm{D}$ and $\mathrm{F}$, respectively). These parameters are proxies for total phytoplankton biomass (Chl-a), relative biomass of diatoms (Fuco:Chl-a) and relative biomass of haptophytes (Hex-fuco:Chl-a). Treatments include initial (t0) and after 3 days nutrient amendment: $\mathrm{Con}=$ control, no amendment; $+\mathrm{N}=$ nitrate; $+\mathrm{NFe}=$ nitrate + iron; $+\mathrm{Si}=$ silicate $;+\mathrm{Mix}=$ nitrate + phosphate + silicate + iron. Values plotted are mean \pm standard deviation. Letters above bars indicate statistical differences amongst treatments (ANOVA, $\alpha=0.05$ ) such that $a$ is different to $b$, and $a b$ is the same as $a$ and $b$. 

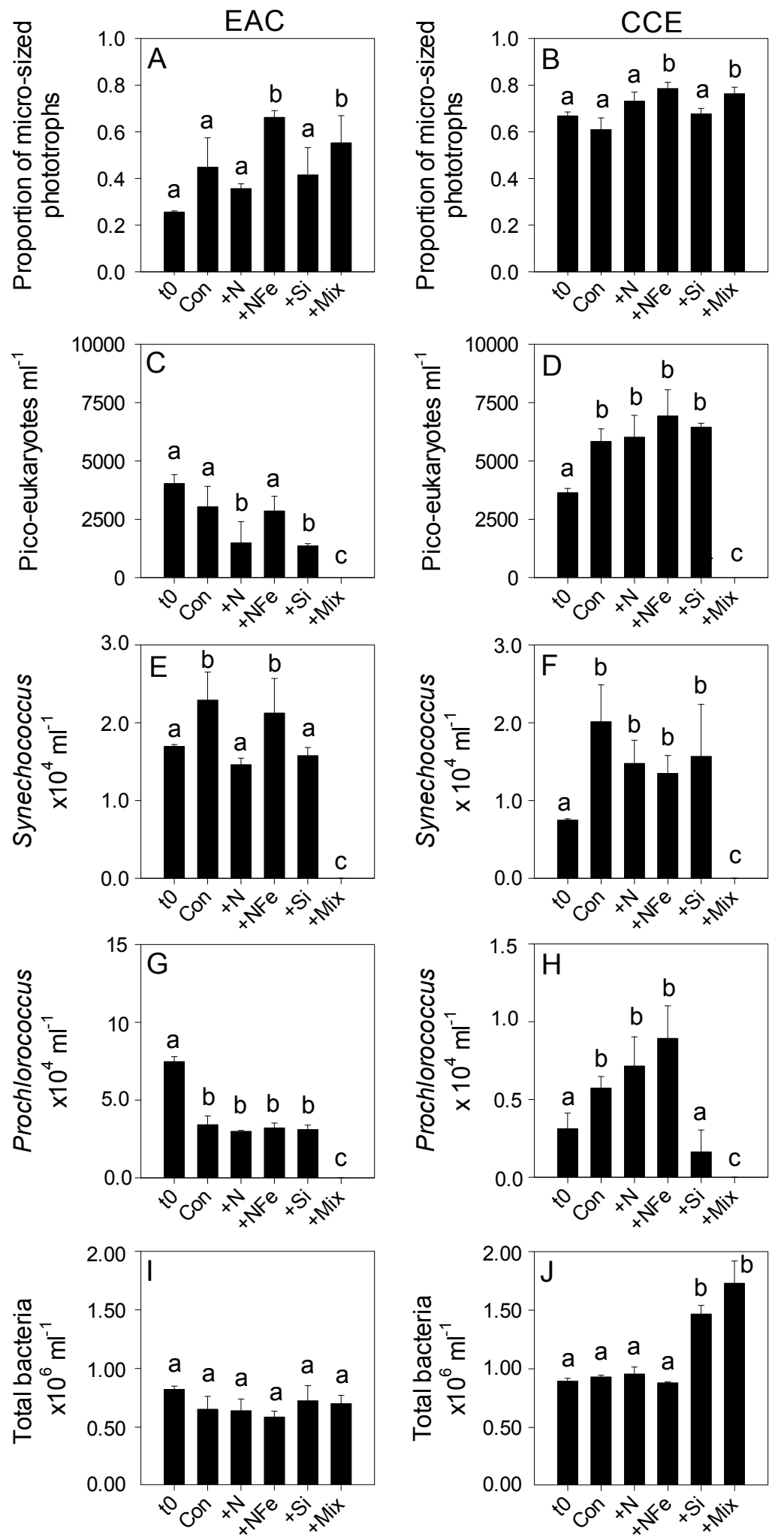
5. Phototrophic and total bacteria responses to nutrient amendment. Proportion of phototrophs larger than $20 \mu \mathrm{m}$ in the EAC (A) and CCE (B), abundance of picoeukaryotes (C and D), abundance of Synechococcus (E and F), abundance of Prochlorococcus (G and H), and abundance of total bacteria (I and J). Treatments as in Figure 4. Values plotted are mean \pm standard deviation. Letters above bars indicate statistical differences amongst treatments (ANOVA, $\alpha=0.05$ ) such that $a$ is different to $b$ and $\mathrm{c}$.

\section{EAC}

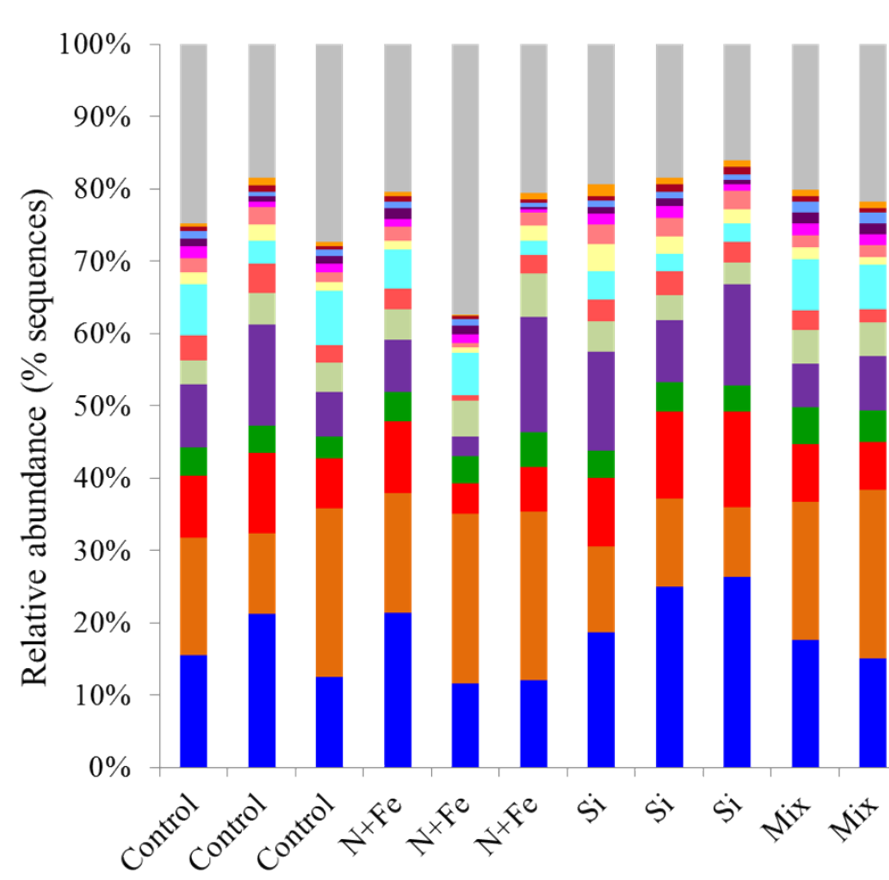

- SAR116_Clade

- Rhodobacteraceae uncultured

- SAR11_Surface_1_uncultured

- SAR11_clade

- Owenweeksia

Other

\section{CCE}

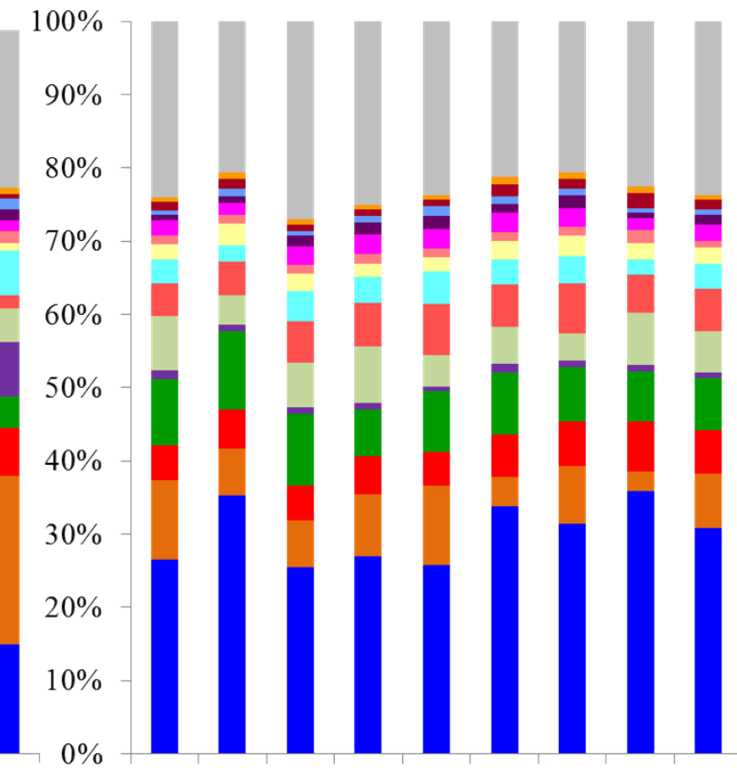

912

913

914

915

916

917

918

919
Synechococcus

- Prochlorococcus uncultured

OCS155_Marine_Group

- NS4 Marine Group

- Candidatus Pelagibacter

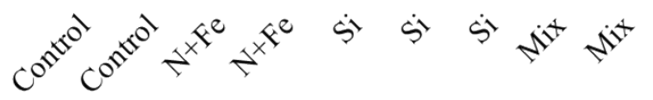

- SAR11_Surface_1

- Chloroplast

SAR86_Clade_uncultured

- NS5 Marine Group

- SAR406_Clade

6. Relative abundance of 16S rRNA operational taxonomic units. Data are shown for sequences with $\geq 97 \%$ sequence similarity to the SILVA database in the EAC (A) and CCE (B) amongst different treatments. For visual simplicity, only the top 15 OTUs are presented, with the upper grey bars representing the remaining $16 \mathrm{~S}$ sequences detected. Control $=$ no amendment; $\mathrm{N}+\mathrm{Fe}=$ addition of nitrate and iron $(10 \mu \mathrm{M}$ and $1 \mathrm{nM}$, respectively), $\mathrm{Si}=$ addition of silicate $(10 \mu \mathrm{M})$ and $\mathrm{Mix}=$ addition of nitrate, phosphate, silicate and iron $(10 \mu \mathrm{M}, 0.625 \mu \mathrm{M}, 10 \mu \mathrm{M}, 1 \mathrm{nM}$, respectively). 

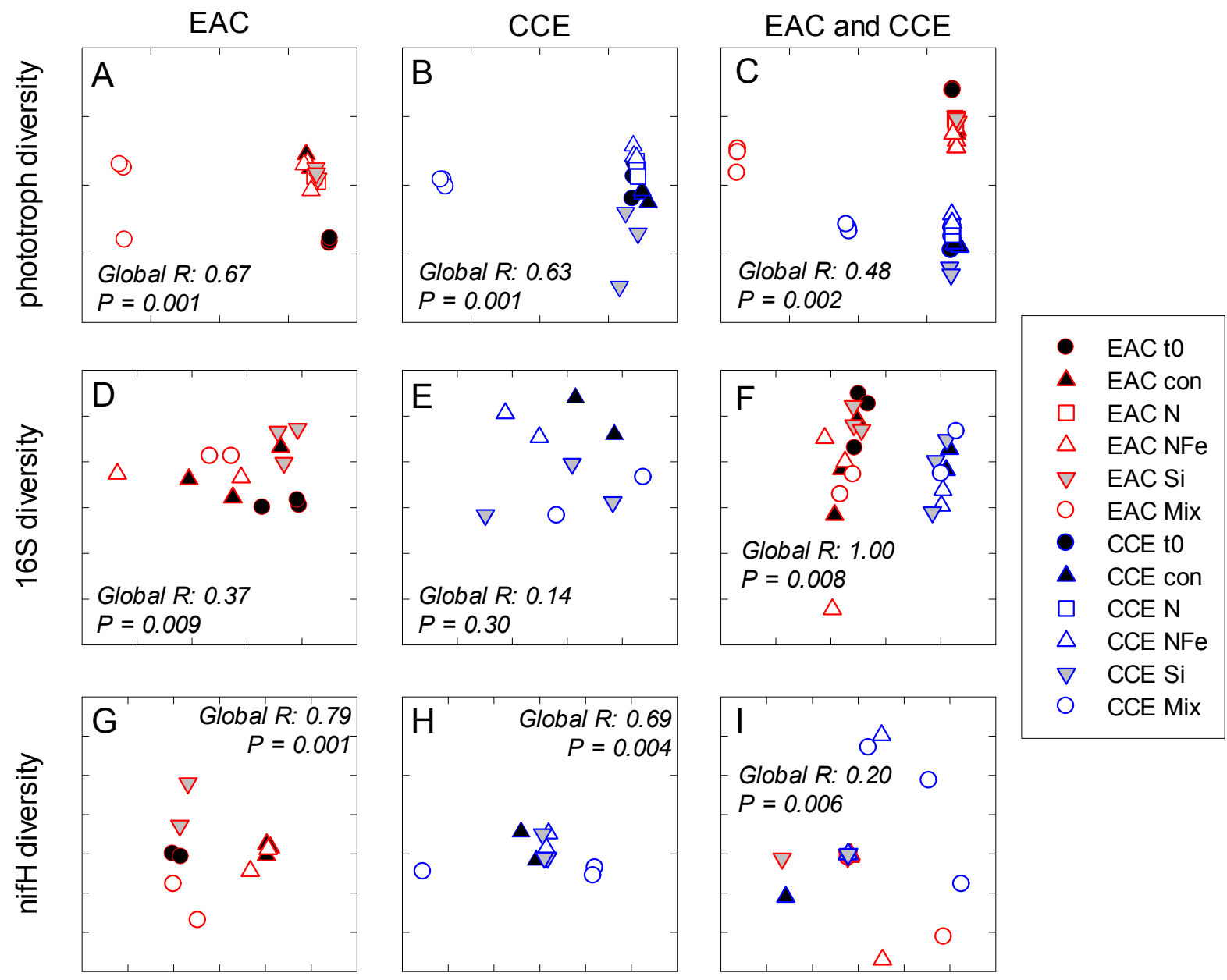

7. Diversity of microbial communities. Multi-dimensional Scaling (MDS) plots of phototrophs (A,B and C), bacteria (D, E and F) and diazotrophs (G, H and I) in the East Australian Current (EAC), cyclonic (cold-core) eddy (CCE) and both the EAC and CCE. Clustering of samples is based on a Bray-Curtis similarity matrix of square-root transformed HPLC pigment concentrations and flow cytometric counts of phototroph abundance, Operational Taxonomic Units from 16S ribosomal genes or nitrogenase NifH subunit genes. Plots on the same row have the same axes scales, to make them directly comparable. Stress values for all plots are $<0.10$. 

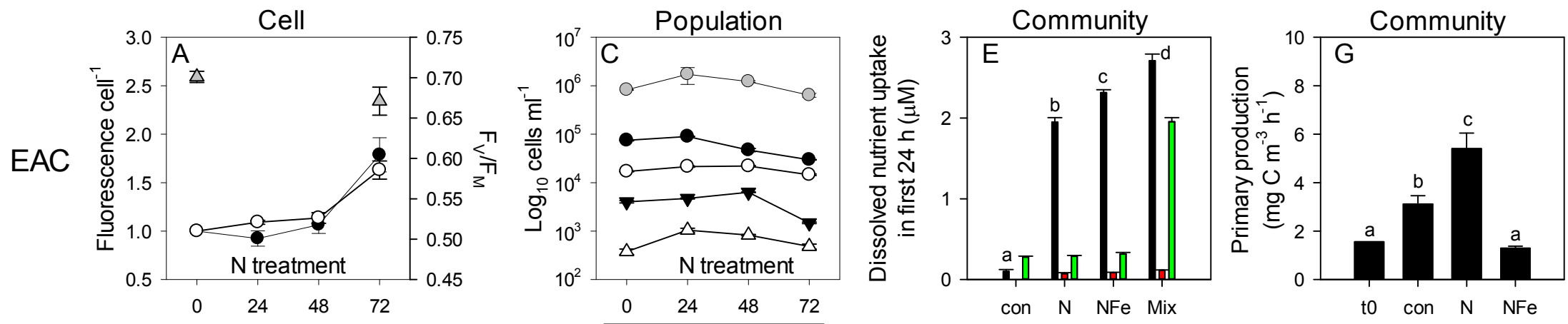

\section{- phycoerythrin -O- chlorophyll-a $\triangle \mathrm{F}_{\mathrm{V}} / \mathrm{F}_{\mathrm{M}}$}
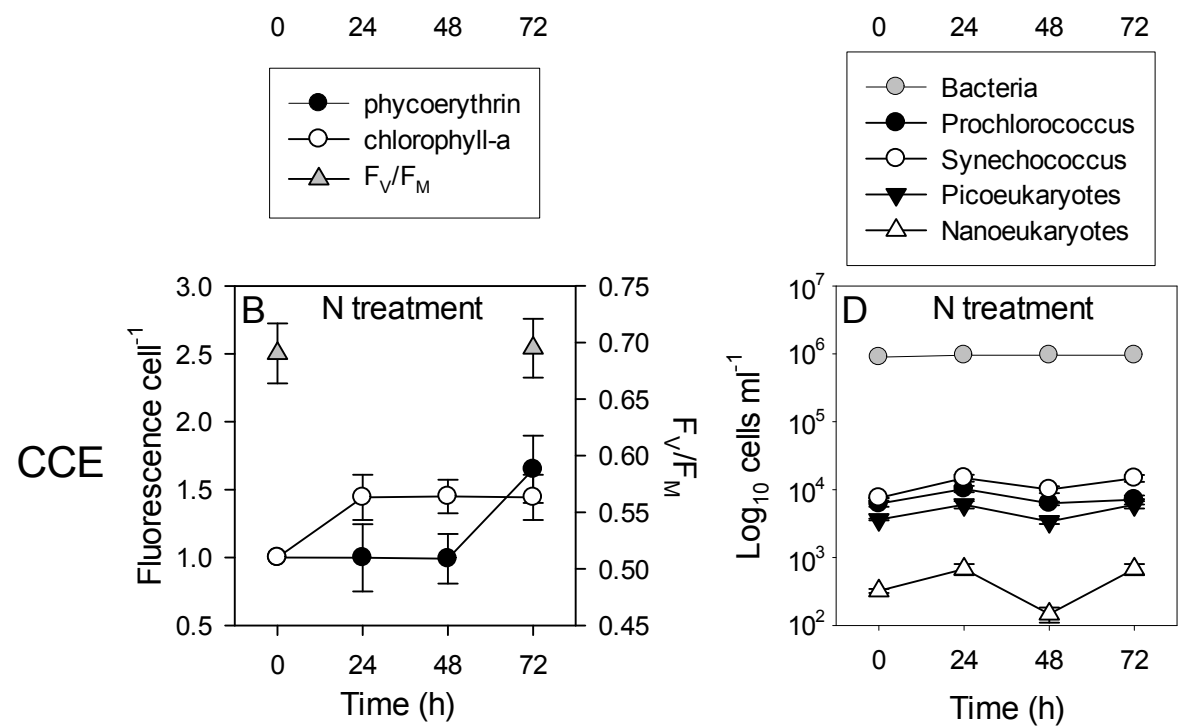
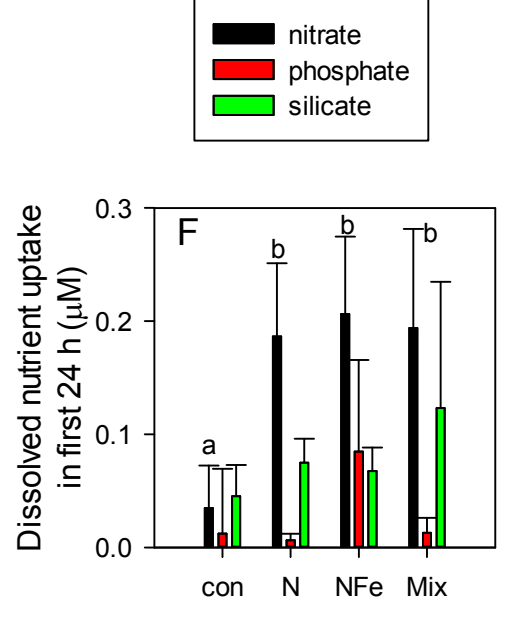

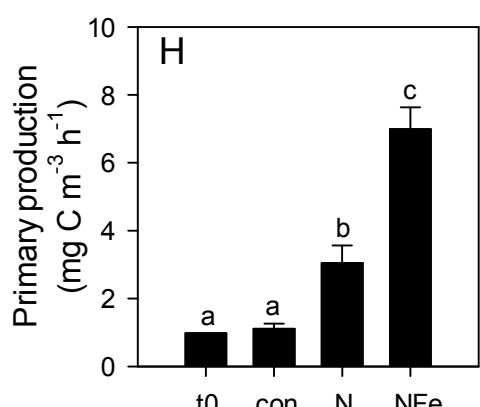

to con $\mathrm{N} N F e$

8. Time-course of microbial responses to nutrient addition. Daily Chl-a and phycoerythrin fluorescence in small picoeukaryotes and Synechococcus, respectively under $\mathrm{N}$ amendment $\left(\mathrm{A}\right.$ and B), together with photosynthetic efficiency $\left(\mathrm{F}_{\mathrm{V}} / \mathrm{F}_{\mathrm{M}}\right)$ of the control phytoplankton assemblage at $\mathrm{t}_{0}$ and $\mathrm{t}_{72}$; Daily abundance of phototrophic and bacterial populations $(\mathrm{C}$ and $\mathrm{D})$ in $+\mathrm{N}$ treatments in the EAC and CCE; Rate of macro-nutrient uptake in the first $24 \mathrm{~h}$ of incubation (E and F); Total carbon fixation by the phytoplankton assemblage in different treatments on day $3(\mathrm{G}$ and $\mathrm{H})$. Values plotted are mean $\pm \mathrm{SD}(\mathrm{n}=3)$ except for plots $\mathrm{C}$ and $\mathrm{D}$ which are mean $\pm \mathrm{SE}(\mathrm{n}=3)$. Letters above bars indicate statistical differences amongst treatments (ANOVA, $\alpha$ $=0.05)$ such that a is different to $\mathrm{b}, \mathrm{c}$ and $\mathrm{d}$. 
